\title{
Sjálfakandi ökutæki á Íslandi: Viðhorf almennings gagnvart
}

\section{nýjum ferđamáta}

\author{
Arnór B. Elvarsson ${ }^{\mathrm{a}, \mathrm{b}}$, Haraldur Sigpórsson ${ }^{\mathrm{b}, \mathrm{c}, \mathrm{d}}$ \\ anfrastructure Management Consultants, 8008 Zürich, Sviss. \\ ${ }^{b}$ WISE-ACT COST Action 16222. \\ 'Verkfræđideild Háskólans í Reykjavík, Menntavegur 1, 102 Reykjavík. \\ dVerkfræđistofa Haralds Sigpórssonar, Suđurhlíđ 38d, 105 Reykjavík.
}

Fyrirspurnir:

Arnór B. Elvarsson

arnor.elvarsson@gmail.com

Greinin barst 5. október 2020

Sampykkt til birtingar 2. desember 2020.

\section{Ágrip}

Sjálfakandi ökutæki eru stundum álitin vera hin fullkomna lausn við samgönguvandamálum samtímans. Undir vissum sviðsmyndum er tæknin talin hafa marga kosti, meðal annars að bæta aðggengi fatlaðra, aldraðra, ungra og annarra sem ekki ferðast jafn auðveldlega nú til dags. Hins vegar, pá gæti tæknin haft í för með sér aðra síður eftirsótta eiginleika undir öðrum svið̌smyndum. Koma tækninnar mun hins vegar ekki raungerast nema hún verði sampykkt af notendunum, p.e. almenningi.

Við̌horf almennings gagnvart tækninni hafa ekki verið skoðaðar fyllilega, og sérstaklega ekki á íslenskri grundu. Í pessari grein er sagt frá niðurstöðum rannsóknar byggðri á spurningalista unnum á samstarfsvettvangi WISE-ACT í Evrópu og víðar. Spurningalisti var lagður fyrir íslenskan almenning og fékkst 561 gilt svar, bæði m.t.t. huglægra pátta og ferðamátavalskönnunar og pau greind eftir lýðfræðilegum páttum svarenda. Eftir samanburð úrtaks og pýðis voru niðurstöður bornar saman við evrópskar niðurstöður Eurobarometer.

Íslenskur almenningur er almennt séð jákvæðari gagnvart sjálfakandi ökutækjum en Evrópubúar í heild, en pó enn tortryggnir. Á sama tíma og farpegum sjálfakandi ökutækja líour betur en óvörơum farpegum í nálægő ökutækisins er víst að̃ stórum hluta fólks liði betur sem farpega með eftirliti öryggisfulltrúa í ökutækinu. Pá er alls óvíst aðð fólk sé tilbúið að senda börn sín með ökutækinu. Svarendur voru almennt jákvæðari gagnvart pví að flytja vörur á milli staða með sjálfakandi tækni. Prátt fyrir petta eru $70 \%$ svarenda jákvæðir gagnvart pví að tæknin sé prófuð í peirra nágrenni og 60\% svarenda jákvæðir gagnvart pví að̃ prófa tæknina sjálfir. Frekari rannsóknir eru lagðar til á grundvelli mælistika sem varpað er fram í greininni.

Lykilorð: ferðamátaval, viðhorf, sjálfakandi, öryggi.

\section{Abstract}

Automated vehicles (AVs) are sometimes considered a silver bullet for contemporary transport problems. For particular scenarios, the technology is believed to have many advantages, such as improving the accessibility of underserved populations. However, the technology may also lead to lesser consequences under other scenarios, with some 
simulations predicting increase in congestion as the modal split shifts towards automation. In any case, the mode choice shift will not be realised without the public acceptence of AVs.

The public opinion towards the technology has not been fully explored, and particularly not in Iceland. This article focuses on the Icelandic results of a cross-national survey. 561 valid responses were recorded, considering attitudinal and stated-mode-choice questions and the responses then analysed as per the sample's socio-demographic attributes and compared to a similar survey performed in other european countries.

The Icelandic public is generally more positive towards automated vehicles than other Europeans, however still skeptical. At the same time as AV passengers feel more safe than vulnerable road users in the vicinity of an AV, AV passengers also feel more safe with an AV supervisor inside the vehicle. It is uncertain whether people will use the vehicles for pick-up and drop-off of children. Respondents are generally more positive that their goods be transported in AVs instead of people. In spite of this, $70 \%$ of respondents were positive that the technology be tried in their neighborhood and $60 \%$ of respondents are positive towards trying the vehicles themselves. Further research is suggested in the outlook of the articles, based on indices and further metrics

Keywords: mode choice, attitude, self-driving, safety.

\section{Inngangur}

Nýlega hefur aukin upplýsingatæknipekking og síhrapandi framleiðslukostnaður skynjara og reiknigetu leitt til umræơu um að̃ sjálfakandi bílar kunna að vera á næstu grösum. Með tilkomu nýrrar tækni sjá framleiðendur sér enn betur fært að̃ innleiða sjálfstýringu í samgöngukerfum og skipta út hefðbundnum ökutækjum eftir pörfum farpega (Iclodean, Cordos \& Varga, 2020; Ainsalu et al., 2018). Eftir pví sem umræðan hefur aukist hafa fræðimenn víða byrjað að greina möguleg áhrif farartækjanna á samgöngur og samfélag. Sjálfakandi ökutæki eru talin fækka umferðarslysum, minnka umhverfisáhrif umferðar og lækka ferðakostnað. Auk pess er talið að̃ nýi ferðamátinn muni auka ferðapægindi og bæta aðgengi fatlaðra, aldraðra, ungra og annarra sem ekki ferðast jafn auðveldlega nú til dags. Tæknin myndi alla jafnan auka eftirspurn eftir ferðum, að öðru óbreyttu (Fagnant \& Kockelman, 2015). Hins vegar er alls óvíst að allt annað reynist óbreytt.

Gefið að tækninni fleyti fram eru umræddar breytingar pó að mörgu leyti háðar sampykki almennings, bæði lagalegu sampykki í gegnum lagasetningu kjörinna fulltrúa og embættismanna auk samfélagslegs sampykkis notenda. Forsendur slíks sampykkis hafa ekki verið skoðaðar fyllilega, og sérstaklega ekki á íslenskri grundu.

Rannsókn pessi er byggó á spurningalista unnum á samstarfsvettvangi WISE-ACT i Evrópu og víðar (Thomopoulos, Pronello, Etzioni, Raposo, Grosso, Polydoropoulou \& Shiftan, 2020). Spurningalisti var lagður fyrir íslenskan almenning og fékkst 561 gilt svar, bæði m.t.t. huglægra pátta og ferðamátavalskönnunar og greind eftir lýðfræðilegum páttum svarenda. Pessi grein segir frá niðurstöðum pessarar rannsóknar á Íslandi og ber pær saman við niðurstöður annarra rannsókna á Íslandi, niðurstöður í evrópskri Eurobarometer rannsókn og niðurstöður annarra fræðimanna. Nýmæli er að̃ nýir ferðamátar séu metnir á pennan hátt hérlendis.

Að lokum eru tekin saman atriði sem taka parf tillit til við stefnumótun er kemur að̃ innleiðingu tækninnar. Höfundar setja upp stika sem hafa má í huga til aơ meta áhrif innleið̌ingarinnar og má nýta við stefnumótun. 
Kafli 2 tekur saman helstu heimildir, kafli 3 fer yfir hönnun spurningalista og dreifingu hans, kafli 4 fer yfir helstu niðurstöður sem að̃ lokum eru teknar til umræðu í kafla 5. 


\section{Heimildarýni}

Í pessum kafla verður farið yfir rannsóknir sem skoða áhrif sjálfvirknivæðingar ökutækja á ferðahegðun fólks og viðhorf peirra til nýrra ferðamáta, nánar tiltekið sjálfakandi bíla í einkaeigu eða sjálfakandi ökutækja í deilipjónustu (e. mobility on demand) hvort sem er í formi farveitna eða almenningssamgangna.

\subsection{Almennt}

Hið bandaríska Society of Automotive Engineers (SAE) flokkar sjálfakandi tækni í bílum á kvarða frá 0-5 (SAE, 2014). Fagnant \& Kockelman greina frá pví aơ fyllilega sjálfakandi bílar (á stigi 5) eru taldir fækka umferðarslysum, minnka umhverfisáhrif umferðar og lækka ferðakostnað (Fagnant \& Kockelman, 2015). Auk pess greina Fagnant \& Kockelman frá pví að̃ talið̃ er að̃ nýi ferðamátinn muni auka ferðapægindi og bæta að̃gengi fatlaðra, aldraðra, ungra og annarra sem ekki ferðast jafn auðveldlega nú til dags. Slík próun er talin muna auka eftirspurn eftir ferðum að̃ öðru óbreyttu. Niðurstöður Harper, Hendrickson, Mangones \& Samaras styðja að̃ síour pjónustaðir samfélagshópar (líkt og fatlað̌ir, aldraðir og ungir) fá greiðara aðgengi að notkun samgangna með nýjum ferðamáta (2016). Fleiri fræðimenn hafa bent á breytingar á hinum ýmsu páttum sem hin nýi ferðamáti gæti haft í för með sér, t.d. umferðarrýmd á hraðbrautum (Hartmann, Motamedidehkordi, Krause, Hoffmann, Vortisch \& Busch, 2017; Narayanan, Chaniotakis \& Antoniou, 2019), aksturshegðun (Le Vine, Zolfaghari \& Polak, 2015), við̌skiptalíkan almenningssamgangna (Becker, 2016; Manser, Becker, Hörl \& Axhausen, 2020), virði ferðatíma (Becker, Bösch, Ciari \& Axhausen, 2016; Schoettle \& Sivak, 2014), bílastæðainnviðir (Elvarsson, Martani \& Adey, 2020), aðgengileiki og afleidd eftirspurn ferða (Meyer, Becker, Bösch \& Axhausen, 2017).

Vanda parf til verka til að̃ áætla breytingu á ferðahegðun almennings, sér í lagi pegar nýr ferðamáti er ómótaður og hefur enn ekki raungerst. Við pessar aðstæður má meta viðhorf almennings með hjálp spurningalista; annars vegar er hægt að spyrja um ferðamátaval svarenda m.v. mismunandi hugsanlegar aðstæður t.d. mismunandi ferðakostnað̆ og ferðatíma (Ben-Akiva \& Lerman, 1985). Hins vegar er hægt að spyrja um viðhorf svarenda til ýmissa huglægra pátta er varða nýjar aðstæður, t.d. áætluô breytingaráhrif nýrra ferðamáta (sjá m.a. Schoettle \& Sivak, 2014). Með pessum upplýsingum má einnig bæta ofangreind líkön byggð á ferðamátavali (t.d. Atasoy, Glerum \& Bierlaire, 2012).

\subsection{Viðhorf almennings til huglægra pátta}

Ýmsar rannsóknir hafa verið gerðar með huglægt mat á áhrifapáttum sjálfakandi tækni pvert á landamæri. Schoettle \& Sivak (2014) voru meðal peirra fyrstu sem dreifðu slíkum spurningalista í Kína, Indlandi, Japan, Bandaríkjunum og Bretlandi auk Ástralíu. Kyriakidis, Happee \& de Winter (2015) komust að pví aõ pvert á 40 mismunandi lönd með 4379 svarendum voru einungis um 2200 svarendur tilbúnir til að svara tölvupóstum á meðan svarandi er farpegi í fyllilega sjálfakandi ökutæki. Petta gefur til kynna að̃ ekki sé endilega víst að farpegar muni ná að vera afkastamiklir m.t.t. vinnu á meðan á ferð peirra stendur. Petta er í samræmi við niðurstöður Schoettle \& Sivak (2014). Correia, Looff, van Cranenburgh, Snelder \& van Arem (2019) hafa einnig velt pessari rannsóknarspurningu fyrir sér með ferðamátavalskönnunum með sjálfakandi ökutækjum sem hönnuð̃ væru að̃ innan sem vinnurými, p.e. með skrifborði og uppréttri setustöðu. Ökutækin hönnuð með vinnurými eru borin saman við̃ ökutæki hönnuð með pægindarými eins og við pekkjum í ökutækjum nú til dags. Virð̌i ferðatíma svarenda var reiknað lægra fyrir sjálfakandi ökutæki hönnuð̃ að̃ innan sem vinnurými t.d. með skrifborði (€5.50 á klst) í samanburði við venjulegt ökutæki (€7.47 á klst) og einnig lægra í samanburði við̌ sjálfakandi ökutæki sem hannað̃ væri til frístunda, t.d. 
með legubekkjum (€8.17 á klst). Höfundar skýrðu pennan mun sem samblöndu pess að svarendur vantreystu annars vegar pví að ferðatímann mætti nýta að fullu til vinnuafkasta og hins vegar vantreystu peir ferðamátanum í heild sinni.

Rannsókn Kyriakidis og félaga gaf einnig til kynna að svarendur hefou ekki miklar áhyggjur af gagnaöflun annarra fyrirtækja og hafa meiri áhyggjur af nálægum sjálfakandi ökutækja (Kyriakidis et al., 2015). Frá pví aơ sú rannsókn var gefin út árið 2015 hefur pó ýmislegt gerst og mikil umfjöllun um notkun persónulegra gagna í misgóðum tilgangi átt sér stað. Sem dæmi má nefna umfjöllun um Cambridge Analytica sem leiddi til gífurlegs taps Facebook á trausti notenda peirra (Weisbaum, 2018).

Í rannsókn Deloitte í Japan, Bandaríkjunum, Pýskalandi, Indlandi, Suour-Kóreu og Kína var sýnt að í öllum löndum sem rannsóknin náoi til vildi almenningur að̃ hið opinbera kæmi að próun og stöðlun sjálfakandi tækni, a.m.k. á einhvern hátt (yfir 85\% í öllum löndum) (Deloitte, 2019).

Niðurstöður Le Vine og félaga benda til pess að pægindapröskuldur farpega sé lægri heldur en pægindapröskuldur ökumanna pegar kemur að̃ hliðarkröftum sem verka á pá sem sitja í bílnum, p.e. farpegar upplifa frekar ópægindi viô að ökutæki taki beygju heldur en ökumenn sjálfir (Le Vine et al., 2015). Með pví að allir gerist farpegar benda Le Vine og félagar á að ljóst sé að̃ sjálfakandi ökutæki purfi að taka beygjur hægar til pess að farpegar upplifi ekki ópægindi. Pá benda Le Vine og félagar (2015) einnig á að neikvæð áhrif hægari umferðar á umferðarrýmd í borgarumhverfi (allavega 4\% auknar tafir, en eykst eftir sviðsmyndum) gæti vegið upp á móti og jafnvel eytt áætluðum ávinningi (um 11-12\%) við að ökutæki aki nær hvoru öðru (Ambühl, Ciari \& Menendez, 2016 ).

Innleiðing sjálfakandi ökutækja gæti leitt til breytinga margra utanaðkomandi pátta (Fagnant \& Kockelman, 2015). Tíoni slysa og óhappa er talin muna hríofalla (Fagnant \& Kockelman, 2015), umferðarrýmd talin aukast (Ambühl et al., 2016), talið er að greiðast muni úr umferðarflækjum (Hartmann et al., 2019) en að sama skapi talið að heildarakstur muni aukast (Meyer et al., 2017). Ferðatími gæti einnig minnkað að̋ öðru óbreyttu ef tími sem fer í bílastæðaleit hverfur par sem ökutækið sér um að leggja án ökumanns/farpega eða heldur áfram að sækja næsta farpega ef um deilipjónustu er að ræða (Fagnant \& Kockelman, 2015).

Kyriakidis og félagar bentu á að fylgni væri milli greiðsluvilja fyrir sjálfakandi tækni og heimilistekna (Kyriakidis et al., 2015). Bæði niðurstöður peirrar rannsóknar og niðurstöður Etzioni, Hamadneh, Elvarsson, Esztergar-Kiss, Djukanovic, Neophytou, Sodnik, Polydoroupoulou, Tsouros, Pronello, Thomopoulos \& Shiftan (2020) sýndu fram á aukinn vilja til að greiða fyrir pjónustu sjálfakandi ökutækja ef við̌komandi hefői pegar reynslu af pví að nota sjálfstýringu á ökutæki sínu. Ekki var skoðað að hvaða leyti slíkur vilji hafði með nýjungagirni við̌komandi að gera eða að hvaða leyti slíkur vilji hafði með jákvæða reynslu af sjálfsstýringu ökutækjanna að gera. Með raunverulegri reynslu af tækni er pó rökrétt að traust til hennar aukist.

Eins hafa Anania og félagar sýnt með eigindlegum rannsóknum að jákvæð umfjöllun um sjálfakandi ökutæki hafơi jákvæð áhrif á upplifun pátttakenda á ferðamátanum (Anania, Rice, Walters, Pierce, Winter \& Milner, 2018).

Eurobarometer 496 spurningalistinn "Expectations and Concerns from a Connected and Automated Mobility" er rannsókn sem framkvæmd var meðal ESB-landa (Eurobarometer, 2020). Spurningalistinn tekur á ýmsum páttum og nefnir t.d. að̃ væntingar Evrópubúa til vöruflutninga séu heldur jákvæðar. Um 62\% allra Evrópubúa eru jákvæððir gagnvart flutningum matvöru með sjálfstýrðri tækni á meðan tæplega $50 \%$ eru jákvæð fyrir flutningum á dýrari vörum. Helsti kostnaður viô vöruflutninga er starfsmannakostnaður og er pví ljóst að 
eftirspurn eftir vöruflutningum gæti aukist töluvert. Benda má á að̃ iõnaðarrisinn Rio Tinto er með að̃ minnsta kosti 150 sjálfakandi vörubíla í rekstri á vinnusvæði sínu í Ástralíu (Fagnant \& Kockelman, 2015).

\subsection{Viðhorf til nýs ferðamáta m.t.t. ferðamátavals}

Harper og félagar (2016) gerðu áhugaverða samantekt á rannsóknum sem byggja á ferðadagbókum. Ferðadagbækur eru hluti af manntalsgögnum um pætti sem hafa áhrif á heild ekinna ökutækjakílómetra. Childress, Nichols, Charlton \& Coe (2015) bentu á að aukning væri á breiðu bili -35\% til 20\% vegna breytinga á ferðatíma, umferðarrýmd, bílastæðagjöldum og veggjöldum. Aðrir eru sammála pví að aukning ekinna ökutækjakílómetra muni eiga sér stað t.a.m. vegna tómra ferða sjálfakandi deilibíla um 11\% (Fagnant \& Kockelman, 2014) og afleiddrar umferðar vegna aukins aðgangs ungra, aldraðra og fatlaðra að̃ samgöngukerfinu (Harper et al., 2016).

Áhrifin á heildarferðatíma og umferðartafir eru pó ekki jafn ótvíræð og eru háð bæð̋ próun umferðarrýmdar, eftirspurn eftir vegplássi á háannatímum og verðlagningu fyrir pjónustu sjálfakandi bíla auk samkeppnishæfni ferðamátans í samanburði við aðra ferðamáta. Pað má vera ljóst að aukin bílaeign muni ekki leiða til minnkunar tafa að öðru óbreyttu enda munu ökumenn, nú farpegar, finna fyrir minni streitu í umferð.

Til að greina heildaráhrifin hafa umfangsmikil líkön verið sett upp og ýmsar sviðsmyndir prófaðar. Strjál vallíkön (e. Discrete choice models) eru pannig notuð til að̃ líkja eftir vali á milli strjálla valkosta, hver meơ notagildi $U$, par sem líkur til að̃ velja ferðamáta i er lýst sem $P_{i}=e^{U_{i}} / \sum_{i} e^{U_{i}}$ (Train, 2003).

Bösch, Ciari \& Axhausen notuðu forritiơ MATSim til að setja upp fulltrúalíkan (e. agent-based model) byggt á Zürich borg, ferðadagbókum og lýðfræðilegum breytum fulltrúa (Bösch, Ciari \& Axhausen, 2016). Með strjálum vallíkönum er pví hægt að̃ líkja eftir ferðamátavali einstaklinga og komust Bösch og félagar að pví að̃ með 10\% bílaflota sjálfakandi leigubíla mætti afgreiða ferðaparfir yfir 95\% allra daglegra ferða fulltrúanna í samfloti með öðrum með að hámarki 10 mínútna biơtíma.

OECD gaf út skýrslu árið 2015 byggða á sambærilegu líkani fyrir Lissabon sem sýndi fram á um 65\% fækkun heildarfjölda bíla í borginni með samspili sjálfakandi ökutækja í samfloti og almenningssamgangna. Ef ferðir eru farnar með sjálfakandi ökutækjum án samflots og án almenningssamgangna leiddi slíkt til 89\% aukningu í eknum kílómetrum. Slíkt á einnig viơ um sviðsmynd par sem 50\% farartækjanna voru sjálfakandi í samfloti og 50\% voru hefðbundnir einkabílar, sem gefur til kynna að̃ umskiptin frá hefơbundnum bílum yfir í sjálfakandi ökutæki munu ekki vera sársaukalaus (OECD, 2015).

Að nota ferðamátavalskannanir til að greina eftirspurn samgangna sýnir áhrif nýrra hugsanlegra samgöngumáta og pjónustu (Yang, Choudhury, Ben-Akiva, Abreu e Silva, \& Carvalho, 2009). Slík strjál vallíkön hafa ekki verið unnin fyrir íslenskar kringumstæður að vitund höfunda, en Etzioni og félagar unnu að̃ rannsókn til samanburðar á Bretlandi, Ungverjalandi, Austurríki, Slóveníu og Kýpur auk Íslands (Etzioni et al., 2020). Val svarenda stóð á milli sjálfakandi bíls í einkaeigu og hefðbundins bíls í einkaeigu. Niðurstöður sýndu að ríkari lönd, hafa síour jákvæo viðhorf gagnvart sjálfakandi ökutækjum. Bílnotendur völdu frekar venjulega bílinn áfram og konur völdu einnig bílinn frekar en sjálfakandi ökutæki. Á Íslandi fengust einnig marktækar niðurstöður fyrir virði ferðatíma eftir ferðamáta, n.t.t. $64 €$ per klst fyrir sjálfakandi ökutæki og $53 €$ per klst fyrir venjulegan bíl, sem gefur annars til kynna að efnameiri velji sjálfakandi ökutæki en líka að svarendur sjái ekki ávinning af pví aơ velja sjálfakandi ökutæki. 


\subsection{Staða pekkingar á Íslandi}

Á Íslandi var fyrst kynnt efni um sjálfakandi ökutæki árið 2015 og rýnt í aðstæour á Íslandi (Sverrir Bollason, 2016). Nokkru síðar birtist lokaritgero frá Háskólanum í Reykjavík par sem farið var yfir áhrif sjálfakandi bíla á hagsmunaaðila (Sigurður K. Ingimarsson og Tómas H. Jóhannesson, 2018). Par má finna ýmis sjónarmið hagsmunaaðila í formi viðtala og mat sérfræðinga á sjálfakandi tækni. Einnig var framkvæmd könnun á huglægum páttum, annars vegar gagnvart almenningi og hins vegar eldri borgurum, en peir eldri reyndust með talsvert neikvæðari við̌horf gagnvart tækninni (Ingimarsson \& Jóhannesson, 2018).

Verkfræðistofan Mannvit gerði samantekt sem metur pætti sem hafa áhrif á umferðarrýmd samgöngukerfa vegna komu sjálfakandi ökutækja. Helstu niðurstöður tóku saman pekktar rannsóknir og bentu á pau áhrif sem sjálfakandi ökutæki og farveitur gætu haft á stofnæðar samgöngukerfisins, t.d. aukin mettun umferðar með meiri töfum og möguleg áhrif á almenningssamgöngur (Mannvit, 2019).

Mannvit gaf einnig út skýrslu um áhrif 5G á samgönguinnviði sem innihélt einnig áhrif fjarskiptatækninnar á umferðarrýmd. Par eru taldar upp niðurstöður úr umferðarflæðilíkani sem gert var af gatnamótum Kringlumýrarbrautar og Miklubrautar. Niðurstöður gefa til kynna að̃ miðað̃ við pá forsendu að 100\% ökutækja væru sjálfstýro, leið̌i tæknipróunin varlega áætlað til 10\% minnkunar á umferðarflæði gatnamótanna, en í besta falli muni tæknin auka umferðarflæði um 12\% (Mannvit, 2020).

Verkfræðistofan Efla greinir frá fyrstu niðurstöðum tilraunaverkefnis Reykjavíkurborgar og Strætó um sjálfakandi almenningssamgöngur hér á landi (Efla, 2020). Eftir að̃ hafa greint styrkleika, veikleika, ógnir og tækifæri greina höfundar innviði á mismunandi leiơum og komast að̃ pví að̃ engar augljósar hindranir standi í vegi fyrir verkefninu pó við̌horf almennings til tækninnar geti haft veigamikil áhrif á framtíðarnotkun ferðamátans (Efla, 2020).

\section{Aðferðafræði og gagnaöflun}

\subsection{Hönnun spurningalista}

Spurningalisti var saminn innan starfshóps WISE-ACT og skiptist hann í prjá hluta:

1. Viðhorfsspurningar um áhrif sjálfakandi ökutækja á bæði ferðahegðun og önnur atriði.

2. Ferðamátavalskönnun á milli hefőbundins bíls, sjálfakandi bíls í einkaeigu eða sjálfakandi bíls í samfloti.

3. Spurningar um svarendur til að greina ferðahegðun og viðhorf eftir lýðfræðilegum páttum.

Spurningalistinn innihélt pví bæői viōhorf út frá huglægum páttum lagðar fram sem stað̌ææfingar með möguleika á að svara á sex punkta Likert-skala frá „mjög ósammála“ (1) til „mjög sammála“ (6). Einnig voru lagðar fram spurningar um ferðamátaval við mismunandi kringumstæður. Spurningalistanum bar að̃ miklu leyti saman við spurningalista Eurobarometer (2020). Peim spurningalista var ekki dreift á Íslandi og eru niðurstöðurnar pví nýmæli á Íslandi. Niðurstöður ferðamátavals hafa verið greindar í samanburði við önnur lönd í grein Etzioni et al. (2020). Pessi grein einblínir hins vegar á niðurstöður huglægra áhrifa einstakra pátta úr fyrsta hluta spurningalistans. Á sama tíma er reynt að bera niơurstöður viðhorfsrannsóknarinnar saman við niðurstöður ferðamátavalskönnunar Etzioni et al. (2020) 
og niðurstöður Eurobarometer (2020). Frekar er greint frá hönnun spurningalistans í (Thomopoulos et al., 2020).

\subsection{Dreifing og svörun}

Spurningalistinn var saminn á ensku og pýddur yfir á íslensku. Spurningalistinn var pýddur til baka á ensku af öorum aðila til að̃ gæta samræmis í spurningum milli landa. Úrbætur voru gerðar og spurningalistanum síðan dreift meðal almennings um alla Evrópu á hverju tungumáli fyrir sig. Par sem gögnum var safnað frá mars 2020 til júni 2020 á meðan áhrif COVID-19 stóðu í hæstu hæðum voru pátttakendur beðnir að hugsa til ferða áður en veiran raskaði peim.

Spurningalistanum var dreift hérlendis til félagsmanna Verkfræðingafélags Íslands, starfsfólks Vegagerðarinnar, starfsfólks Skipulagsstofnunar, starfsfólks og nemenda Háskóla Íslands, starfsfólks og nemenda Landbúnaðarháskóla Íslands, aðildarfyrirtækja Bílgreinasambandsins og fleiri aðila auk persónulegra tengiliða höfunda skv. Thomopoulos et al. (2020). Svörun var góð. 1.068 aðilar opnuðu spurningalistann en 561 svarandi búsettir á Íslandi kláruðu spurningalistann, rúm 0,15\% íbúa, og má pví gera ráo fyrir u.p.b. 2,5\% svörunarhlutfalli. Rannsóknin var send um pann tíma sem nemendur Hí fóru í sumarleyfi, e.t.v. eru tölurnar par ofmetnar. Ekki var boðin póknun fyrir svörun spurningalistans.

Tafla 1 tekur saman stærðir hópanna sem dreift var til.

Svörun var góð. 1.068 aðilar opnuðu spurningalistann en 561 svarandi búsettir á Íslandi kláruðu spurningalistann, rúm 0,15\% íbúa, og má pví gera ráo fyrir u.p.b. 2,5\% svörunarhlutfalli. Rannsóknin var send um pann tíma sem nemendur Hí fóru í sumarleyfi, e.t.v. eru tölurnar par ofmetnar. Ekki var boðin póknun fyrir svörun spurningalistans.

Tafla 1: Dreifingaraðilar og stærð hóps sem dreift var til

\begin{tabular}{|c|c|}
\hline Dreifingaraðili & Stærð hóps \\
\hline $\begin{array}{l}\text { Verkfræòingafélag } \\
\text { Íslands }\end{array}$ & 4‘000 \\
\hline Vegagerðin & 350 \\
\hline Skipulagsstofnun & 30 \\
\hline $\begin{array}{l}\text { Háskóli Î́slands } \\
\text { (starfsmenn) }\end{array}$ & $1^{‘} 676$ \\
\hline $\begin{array}{l}\text { Háskóli Î́slands } \\
\text { (nemendur) }\end{array}$ & $14 ‘ 992$ \\
\hline Bílgreinasambandið & 119 \\
\hline $\begin{array}{l}\text { Landbúnaðarháskóli } \\
\text { Íslands }\end{array}$ & 350 \\
\hline Persónulegir tengiliðir & $1 ‘ 000$ \\
\hline $\begin{array}{l}\text { Samtals. } \\
\text { Svarhlutfall }\end{array}$ & $\begin{array}{l}\text { Upb. } 22.500 \\
2.5 \%\end{array}$ \\
\hline
\end{tabular}

Reynt var að ná til fleiri félagasamtaka en peirra sem greint er frá í ofangreindri töflu til að fá sem fjölbreyttastan hóp svarenda. Fylgst var með lýðfræðilegri lýsingu úrtaksins eftir pví sem svörum var safnað og hún borin saman við lýofræðilega lýsingu Hagstofunnar (Hagstofa, 2020). Pá var athugað hvort grípa pyrfti inn í, p.e. óska eftir svörun sérstaklega frá ákveðnum samfélagshópum. Ekki var talin vera pörf á slíku, pó vissulega hafi verið reynt aơ ná til breiðari hóps.

Sjá má lýðfræơilega lýsingu úrtaksins í næsta kafla. 


\section{Niðurstöठur}

Áður en greint er frá niðurstöðum rannsóknarinnar er gengið úr skugga um hvort nota megi niðurstöðurnar og yfirfæra niðurstöður úrtaksins á alla íbúa. Pví var athugað eftir að̃ svörun var lokið hvort úrtakið væri lýðfræðilega sambærilegt gögnum Hagstofu íslands (Hagstofa, 2020).

\subsection{Lýðfræðileg lýsing}

Í samanburôi úrtaksins við pýði mannfjölda (sjá Tafla 2) má strax átta sig á pví að hlutfall svara sem skilgreindu sig karlkyns er yfirgnæfandi hærra en hlutfall kvenna. Viő svörun sést að of fáir íbúar á aldrinum 16-19 ára og 80+ tóku pátt til að fá fullkomna samsvörun úrtaksins við pýði mannfjölda (0\% í samanburði við 6\% fólksfjölda á aldrinum 16 ára og uppúr). Hlutfall svarenda á aldursbilinu 50-69 ára var of hátt m.v. hlutfall sama aldursbils af heildarfjölda pýoxisins pýôisins (40\% í samanburði vio 28\%). Hlutfallslega stór hópur skilgreinir sig í „fullu námi“ en aftur á móti skilgreinir um $0 \%$ stöđu sína á atvinnumarkaði undir „,annað“ prátt fyrir að 9\% íbúa á Íslandi heyrðu til pess flokks síðasta ársfjórðung ársins 2019 (Hagstofa, 2020). Að öðru leyti næst góð samsvörun úrtaks við atvinnustöðu m.v. mannfjölda á aldursbilinu 1674 ára.

Lítil sem engin svörun barst frá einstaklingum sem hafa einungis grunnskólamenntun, prátt fyrir að̃ um 30\% íbúa búi ekki yfir frekari menntun skv. gögnum Hagstofu. Um 85\% svarenda eru með háskólapróf eða frekari menntun pó einungis 35\% íbúa hafi náð slíku menntunarstigi. 98\% svarenda á gilt ökuskírteini, pó einungis 92\% á aldrinum 16-74 ára eigi slíkt á Î́slandi.

Gjarnan er hægt að sýna fram á pað að samsetning heimilis hafi bein áhrif á ferðamátaval. T.d. hafa margir fræðimenn komist að̃ pví að heildartekjur heimilis hafi áhrif á ferðahegðun fólks (Jara-Diaz, 1998). Auk pess hefur staðsetning heimilis og aðgengi íbúa að̃ bíl (mælt með fjölda bíla á heimili) að sjálfsögð̃u áhrif á ferðavenjur. Tafla 3 ber heimili svarenda saman við̃ gögn Hagstofu. 
Tafla 2: Svarendur: Samanburður úrtaks og mannfjölda

\begin{tabular}{|c|c|c|c|}
\hline & & Úrtak & Mannfjöldi \\
\hline \multirow[t]{2}{*}{ Mannfjöldi } & Samtals & 561 & $364^{\prime} 134$ \\
\hline & Aldursbil 16-74 & 539 & 291'394 \\
\hline \multirow[t]{3}{*}{ Kyn } & Karlkyns & $69 \%$ & $51 \%$ \\
\hline & Kvenkyns & $31 \%$ & $49 \%$ \\
\hline & Annaó & $0 \%$ & $0 \%$ \\
\hline \multirow[t]{9}{*}{ Aldur } & Yngri en 16 & $0 \%$ & $20 \%$ \\
\hline & $16-19$ & $0 \%$ & $5 \%$ \\
\hline & $20-29$ & $19 \%$ & $15 \%$ \\
\hline & $30-39$ & $16 \%$ & $15 \%$ \\
\hline & $40-49$ & $16 \%$ & $13 \%$ \\
\hline & $50-59$ & $21 \%$ & $12 \%$ \\
\hline & $60-69$ & $19 \%$ & $10 \%$ \\
\hline & $70-79$ & $7 \%$ & $6 \%$ \\
\hline & $80+$ & $1 \%$ & $3 \%$ \\
\hline \multirow[t]{7}{*}{$\begin{array}{l}\text { Staða á } \\
\text { atvinnumarkaði }\end{array}$} & Launpegi & $65 \%$ & $68 \%$ \\
\hline & Sjálfstætt starfandi & $6 \%$ & $6 \%$ \\
\hline & Fyrirtækjaeigandi & $2 \%$ & $3 \%$ \\
\hline & Atvinnulaus & $2 \%$ & $3 \%$ \\
\hline & Í fullu námi & $12 \%$ & $5 \%$ \\
\hline & Ellilífeyrispegi & $9 \%$ & $6 \%$ \\
\hline & Annad & $0 \%$ & $9 \%$ \\
\hline \multirow[t]{5}{*}{ Hæsta menntunarstig } & Grunnskóli eða sambærilegt & $1 \%$ & $30 \%$ \\
\hline & Framhaldsskóli & $12 \%$ & $35 \%$ \\
\hline & Háskólapróf & $49 \%$ & $20 \%$ \\
\hline & Framhaldsháskólapróf & $36 \%$ & $15 \%$ \\
\hline & Annad & $0 \%$ & $0 \%$ \\
\hline \multirow[t]{2}{*}{ Ökuskírteini } & Já & $98 \%$ & $91 \%$ \\
\hline & Nei & $2 \%$ & $9 \%$ \\
\hline \multicolumn{4}{|c|}{$\begin{array}{l}\text { Ath: Ökuskírteini mannfjölda m.v. heildartölu útgefinna ökuskírteina deilt með } \\
\text { mannfjölda á aldri 16-74. Staða á atvinnumarkaði miðast einnig við mannfjölda } \\
\text { á sama aldursbili. }\end{array}$} \\
\hline Heimild: & \multicolumn{3}{|c|}{$\begin{array}{l}\text { Eigin gögn, Hagstofa (2020) og Ríkislögreglustjóri } \\
(2020)\end{array}$} \\
\hline
\end{tabular}


Við staðsetningu heimilis má sjá að hlutfallslega eru margir svarendur á höfuððborgarsvæðinu, pá sérstaklega vestan Elliðaáa (samtals 36\% svarenda í stað 21\% íbúa í póstnúmerum 101-108 og 170). Sú hlutfallslega mikla svörun er helst á kostnað íbúa á Reykjanesi (2\% í stað 8\%) NV- og Austurlandi (8\% í stað 17\%) og Suðurlandi (0\% í stað 2\%). 34\% úrtaksins tilheyrir heimili par sem heildartekjur pess fyrir skatt eru á bilinu 0-899 púsund. Á Íslandi eru pó 55\% heimila á pessu bili. Hlutur lágtekjuheimila í úrtakinu er ekki nægilega stór.

Eins bendir tekjudreifing úrtaksins til pess að heimili á Íslandi séu mun tekjuhærri en gögn Hagstofu gefa til kynna. Slík bjögun kann aơ vera beintengd við litla svörun rannsóknarinnar á landsbyggðinni í samanburði við höfuðborgarsvæðið, par sem heimilistekjur eru óneitanlega hærri (Byggðastofnun, 2018). Eins er úrtakið mun menntaðra en pýðið og skiljanlegt að̃ tekjumunur sé einnig eftir pví.

M.t.t. heimilisstærðar er hlutfallslega lítil svörun frá svarendum í eins íbúa heimili (12\% í stað 36\% íbúa á Íslandi) í samanburði viò stór heimili með fleiri en 5 íbúa (14\% í stað 8\%). Petta kann aơ vera vegna lítillar svörunar í bæői yngsta og elsta aldurshópi sem líklegastir eru til pess að búa yfir einstaklingum sem búa einir.

Eins eru svarendur með hlutfallslega fleiri bíla á heimili en íbúar á Íslandi. Petta helst í hendur við pá staðreynd að̃ svarendur bjuggu við hlutfallslega hærri heildartekjur heimilis en íbúar á Íslandi og má pví rekja til hærri velmegunar svarenda. Hlutur bíllausra heimila í úrtakinu er of lítill (4\% í stað 11\% heimila sem eru án bíls).

\subsection{Viðhorf almennings til ýmissa pátta sjálfakandi ökutækja}

Hafa ber í huga að̃ hér er spurt um einstaka pætti á einangraða vegu undir hugsanlegum aðstæðum. Vel kann að vera að aðrir pættir eins og t.d. verð vegi pyngra pegar kemur að mati á ferðamátum. Slíkt er athugað í strjálum vallíkönum sem ekki er frekar gert skil í pessari grein.

\section{Upplifun öryggis í nálægð við ökutæki}

Spurt var um pægindi í nálægð við sjálfakandi ökutæki í umferð eftir pví hvaða ferðamáta maður ferðaðist með. Mynd 1 sýnir að óvörðum vegnotendum sem ekki ferðast í bíl, hvort sem er sjálfakandi eða hefơbundnum, líður síður vel í nálægð sjálfakandi ökutækja. Einnig má sjá að fótgangandi finna síour fyrir ógn af sjálfakandi ökutækjum enda eru fótgangandi síour líklegir til að deila vegrými með sjálfakandi ökutækjum á gangstéttum á meðan hjólreiðafólk, rafskutlu- og mótorhjólanotendur munu gera pað á vegum, sem útskýrir muninn á fótgangandi og öorum utan bíls. 


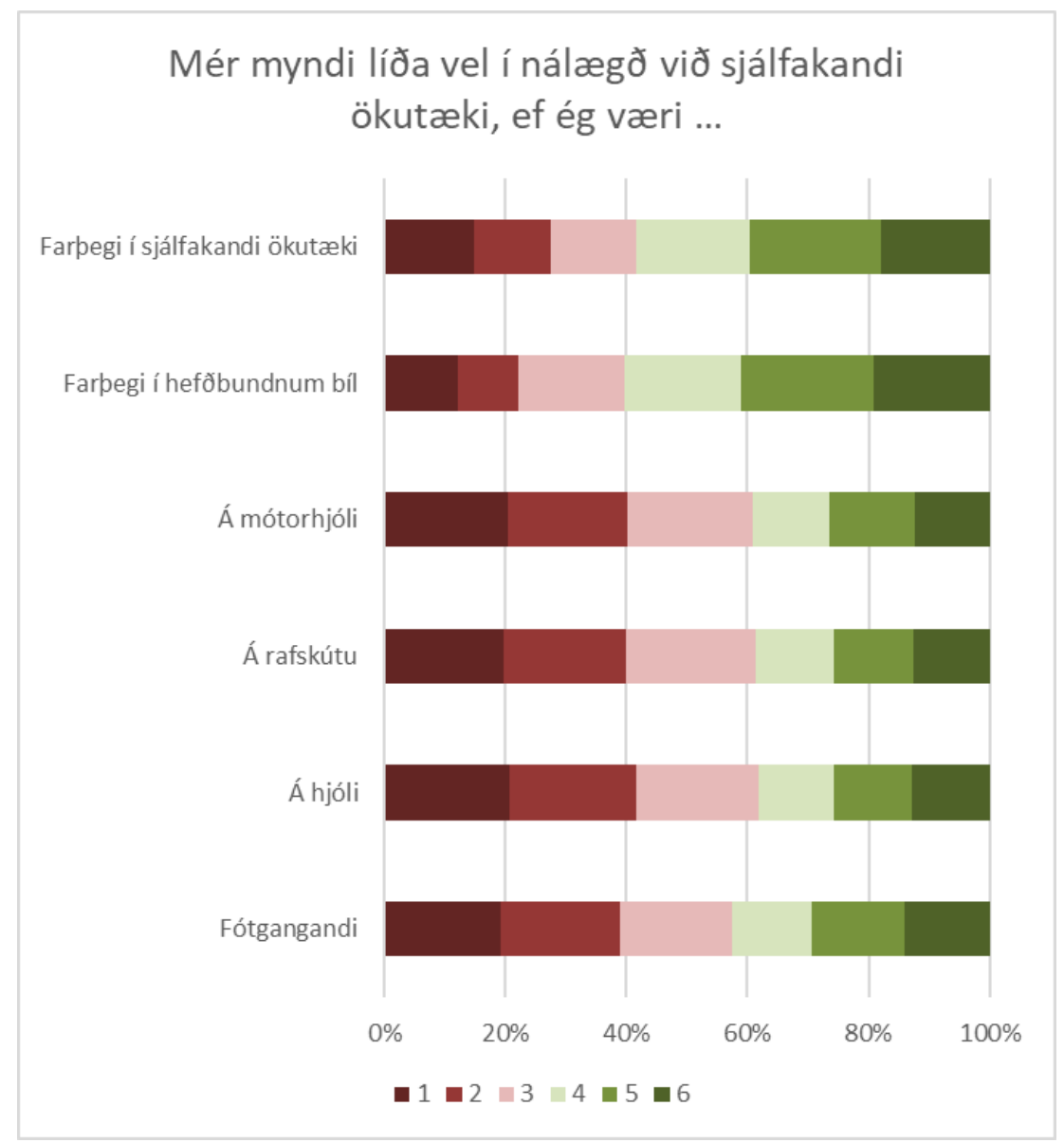

Mynd 1: Upplifun öryggis vegfarenda í nálægð við sjálfakandi ökutæki

Almennt má fullyrðaa að̃ um 60\% farpega í öðrum sjálfakandi ökutækjum og í hefobundnum bílum gefa upp jákvæða öryggistilfinningu (einkunn 4-6) í samanburði við 40\% notenda annarra ferðamáta. Petta er töluvert hærra en niðurstöður Eurobarometer, gefa til kynna að 37\% evrópubúa líði vel í nágrenni sjálfakandi ökutækis sem fótgangandi vegfarandi, um 30\% á hjóli, rafskútu eða mótorhjóli og í kringum 40\% í bílum, hvort sem er hefobundnum eða sjálfakandi (Eurobarometer, 2020). 


\section{Öryggi á meðan á ferð stendur}

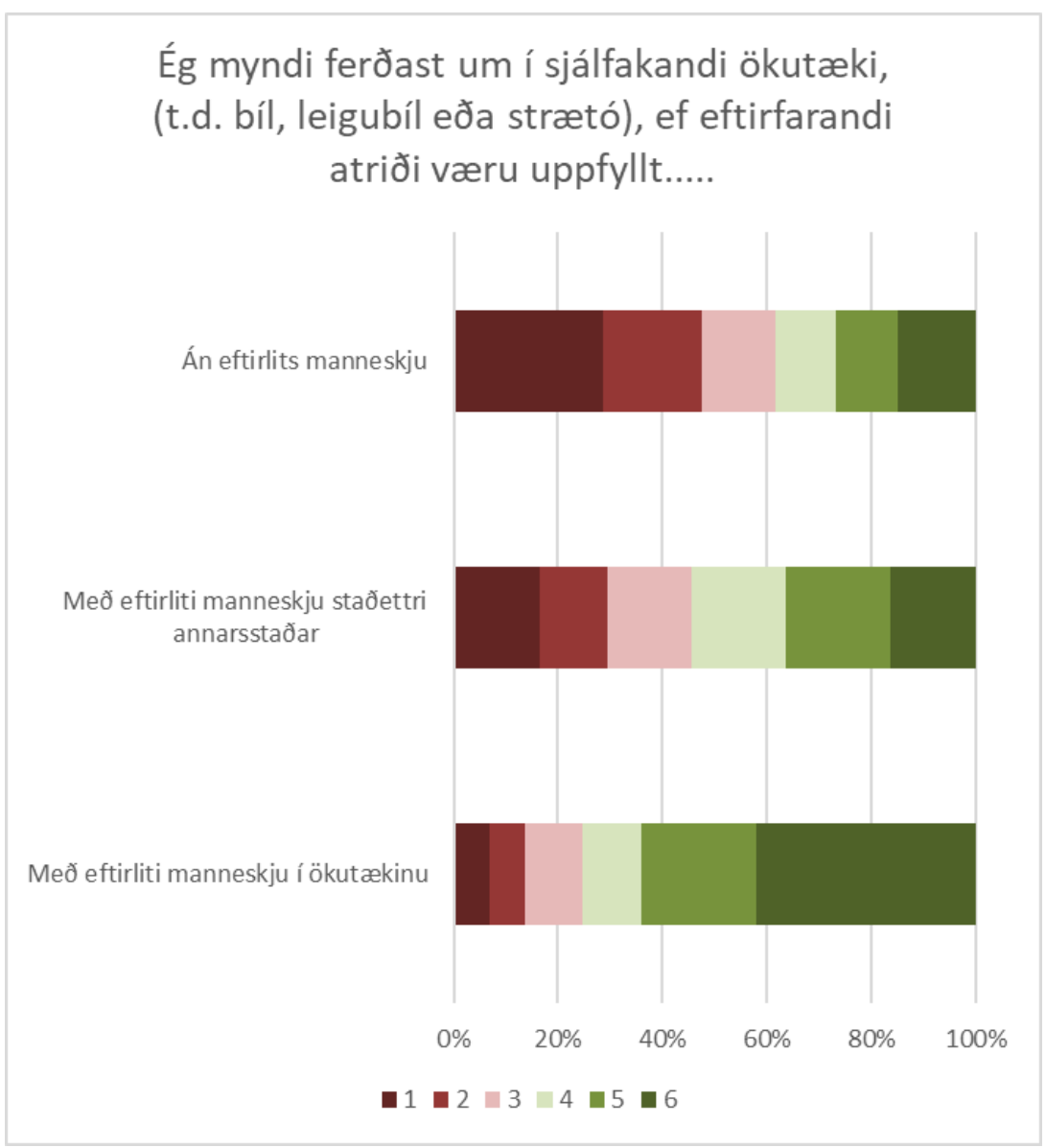

Mynd 2: Upplifun öryggis á meðan á ferð̃ stendur

Mynd 2 sýnir að einungis 40\% svarenda væru jákvæðir fyrir pví að ferðast með sjálfakandi bílum án eftirlits (sbr. 22\% í Evrópu) (Eurobarometer, 2020). Með eftirliti eykst téð hlutfall og stendur í u.p.b. $75 \%$.

Mikilvægur páttur í ferðamátavali vegfarenda er upplifun öryggis, en slíkt er ekki sjálfgefið. Par sem greint hefur verið frá pví að um 94\% umferðarslysa eru af mannavöldum (NHTSA, 2015) hefur pað̋ verið notað sem röksemdafærsla til að staðfesta ávinning sem fylgir sjálfakandi ökutækjum enda muni vera hægt að útrýma 94\% slysa með hjálp tækninnar (Fagnant \& Kockelman, 2015). Prátt fyrir pennan áætlaða ávinning má skilja niðurstöður á Mynd 2 á annan hátt. Upplifun um öryggi einstaklinga sé að̃ mörgu leyti háo pví að̃ vita að maður sjálfur, eða par til bær aðili, sé við stjórn. Pá er einnig átt við að í deildum ferðum og/eða í strætisvögnum skipti pað máli að̃ ekki stafi hætta af meðfarpegum sbr. (Sarriera, Álvarez, Blynn, Alesbury, Scully \& Zhao, 2017). Fyrir vikið er umræða um eftirlit í sjálfakandi ökutækjum talin eiga mikilvægt erindi.

Minna en 30\% væru tilbúnir til að leyfa börnunum sínum að ferðast í sjálfakandi ökutæki án eftirlits en pó um 70\% með eftirliti manneskju í bílnum (sjá Mynd 3). Pað er meira traust gagnvart sjálfakandi ökutækum í samanburði við gögn Eurobarometer par sem 19\% treystu að̃ senda börn sín án eftirlits og 58\% undir eftirliti. 


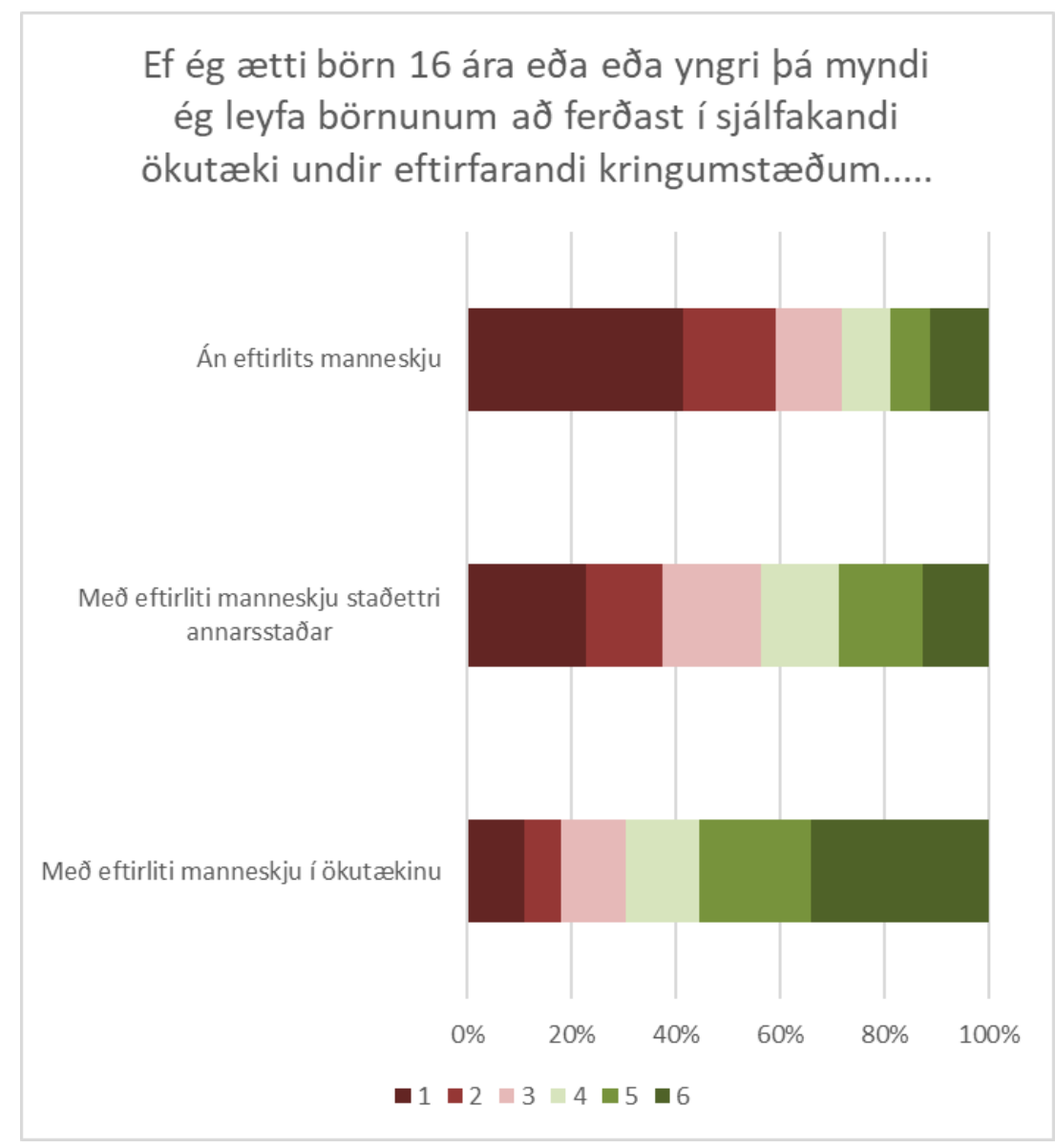

Mynd 3: Upplifun öryggis að börn ferðist í sjálfakandi ökutækjum

Með samanburði við fyrri myndir sýnir Mynd 3 að óskir svarenda um eftirlit stafar ekki einungis af áhættu eða ópægindum við að ferðast með öðru ókunnugu fólki. Eftirlitið er einnig parft við stýringu bílsins. Einnig er ljóst að upplifun öryggis barna getur vegið pungt pegar kemur að pví að leyfa börnum sínum aðo nota pjónustu farartækjanna. Mögulegur ávinningur tæknipróunarinnar er að gefa foreldrum kost á pví að skutla börnum í skóla og frístundir með ökutækjunum. Pessi ávinningur kann að hverfa ef vantraust foreldra til tækninnar er pað mikiơ að̃ pau purfi sjálf að sinna eftirliti með börnum sínum er pau ferðast á milli stað̃a (Kyriakidis, Sodnik, Stojmenova, Elvarsson \& Thomopoulos, 2020). 


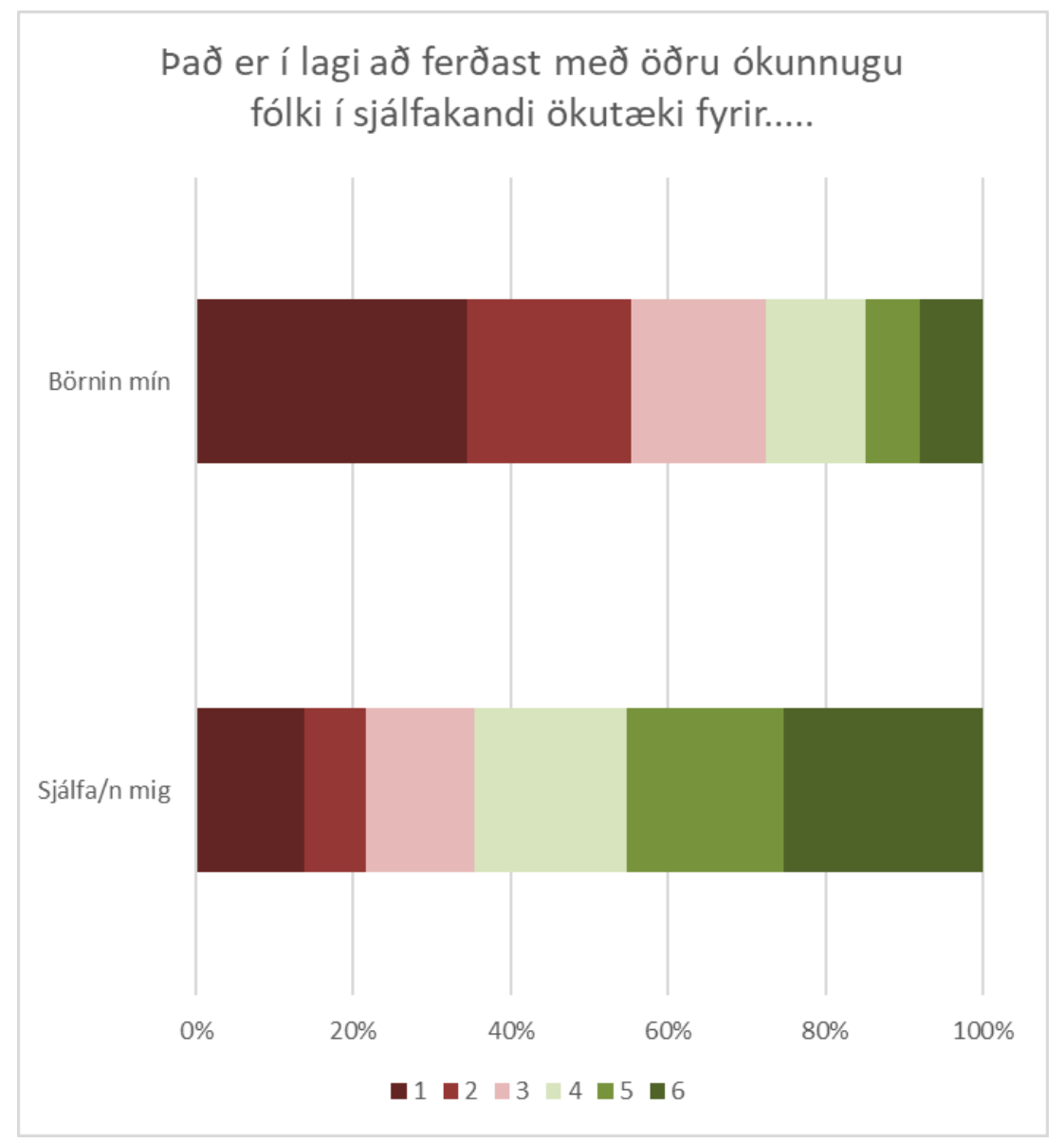

Mynd 4: Upplifun öryggis með ókunnugu fólki.

Ekki er víst að pessi páttur vegi jafn pungt pegar öryggi pjónustunnar hefur sannað sig, en pangað til að peirri óvissu hefur verið eytt er enn ósvarað hvort ferðalangar reynist tvístíga varðandi öryggi ökutækjanna.

\section{Nýting ferðatíma sem farpegi í sjálfakandi ökutæki}

Gjarnan hefur verið haldið fram að helsta framför með sjálfakandi tækni sé að ökumaður verði að̃ farpega, og losni pví við skyldur sem felast í pví að fylgjast með umferðinni og akstrinum. Á móti kæmi að̃ hægt væri aơ nýta tímann til og frá vinnu eða skóla á afkastamikinn hátt. Mynd 5 sýnir hins vegar að pað að „vinna“ er næst-óvinsælasta athöfn (e. Activity) til að stunda á meðan á ferð stendur.

Aðeins 50\% eru jákvæðir gagnvart pví að vinna. Aftur á móti eru yfir $80 \%$ manns jákvæðir gagnvart pví að horfa út um gluggann og um 75\% jákvæði gagnvart pví að fylgjast með hegðun bílsins. Pessu ber saman við fyrri niðurstöður fræðimanna (Kyriakidis et al, 2015; Schoettle \& Sivak, 2014; Correia et al., 2019). 


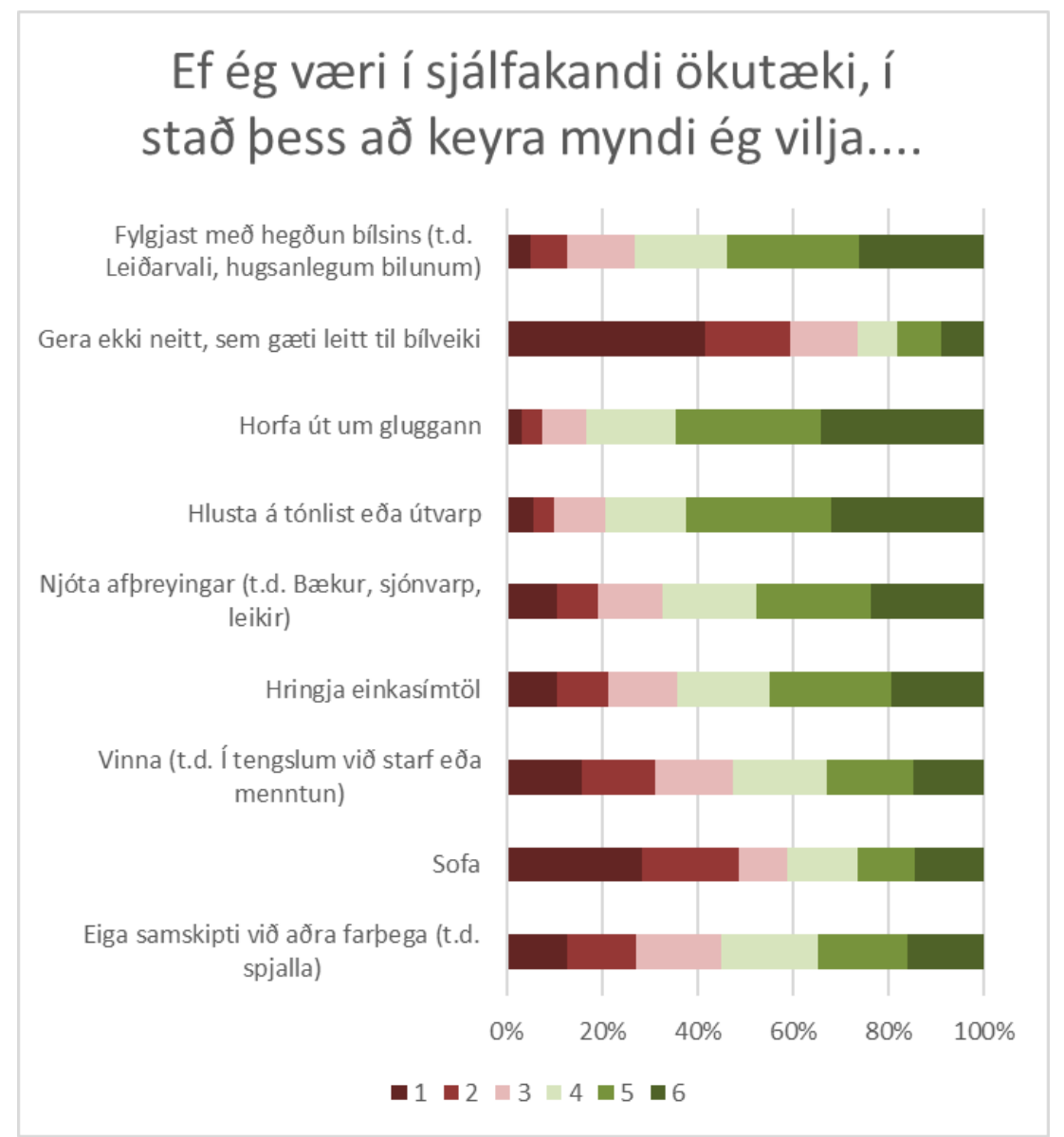

Mynd 5: Á meðan að ferðast er með sjálfakandi ökutæki

\section{Bílaeign}

Út frá Mynd 6 má sjá dreifingu á pví hvenær fólk mun taka sig til og kaupa sjálfakandi bíl. Bera má pessa próun saman viơ innleiðingu Rogers á nýjungum sem dreifir kaupendum í hópa á milli svokallaðra „Early adopters“ (snemmbúna aðllagendur) og „laggards“ (slórara) (Rogers, 1962) en dreifing grænu svörunarinnar virðist pó vera normaldreifo líkt og Rogers leggur til. 


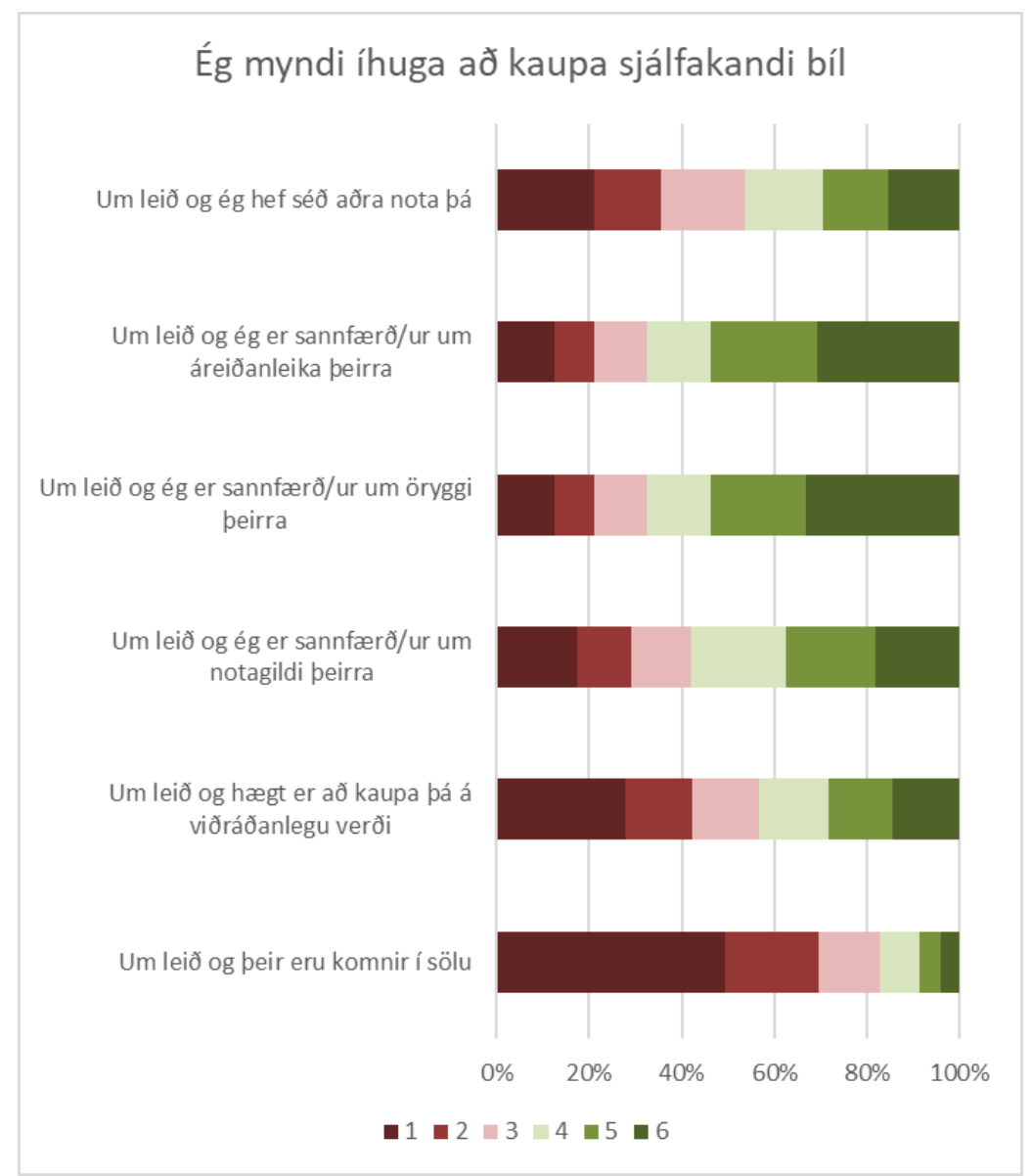

Mynd 6: Pættir sem spila inn í við tímasetningu á kaupum á sjálfakandi bíl.

Bösch og félagar hafa sýnt fram á að útlagður kostnaður við hverja ferð gæti verið töluvert lægri fyrir sjálfakandi bíla í einkaeigu í samanburði við aðra ferðamáta (Bösch, Becker, Becker \& Axhausen, 2018). Hins vegar ef litið er til heildarkostnaðar hverrar ferðar væri mun dýrara að eiga sjálfakandi bíl. Pað er pví ljóst að peir sem pegar eiga bíl munu alltaf kjósa að nota bílinn sé hann í boð̌i.

\section{Vöruflutningar}

Svarendur eru mun jákvæðari gagnvart vöruflutningi eigin vara í samanburði við fólksflutninga. Mynd 7 sýnir, líkt og með við̌horf til fólksflutninga á Mynd 2 og Mynd 3 að traust til ferða með ökutækjunum eykst með auknu eftirliti. Samanburður á Mynd 2 og Mynd 7 sýnir að svarendur eru jákvæðari gagnvart pví að vörur peirra séu fluttar með sjálfakandi ökutækjum frekar en fólk. Petta gæti auðveldað flutningafyrirtækjum að fá sampykki fyrir notkun ökutækjanna, en pó með öryggisupplifun annarra vegfarenda í huga (sjá „Upplifun öryggis í nálægð við ökutæki“) 


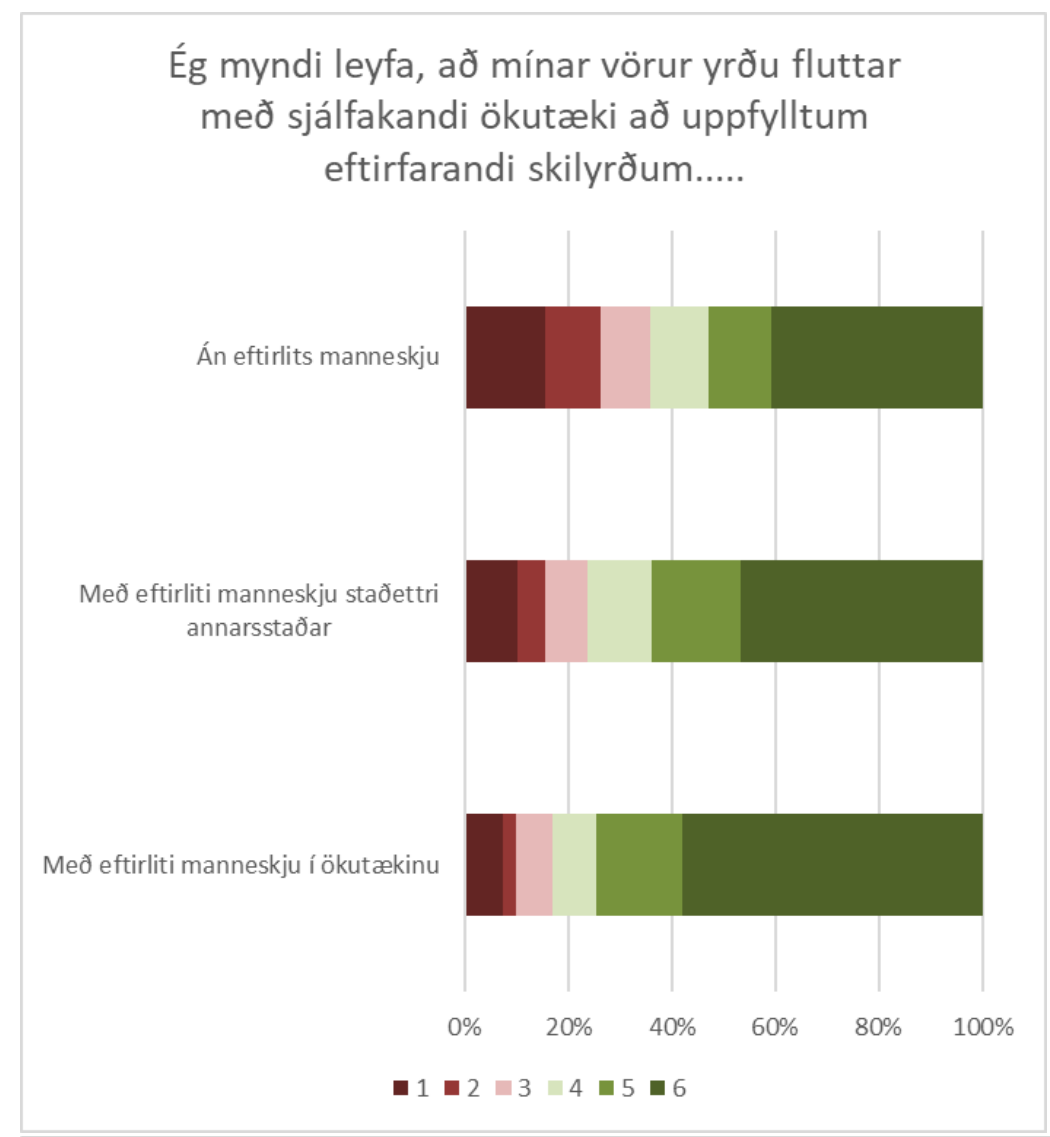

Ég myndi nota sjálfakandi ökutæki til að ná í og skila af sér eftirtöldum vörum.....

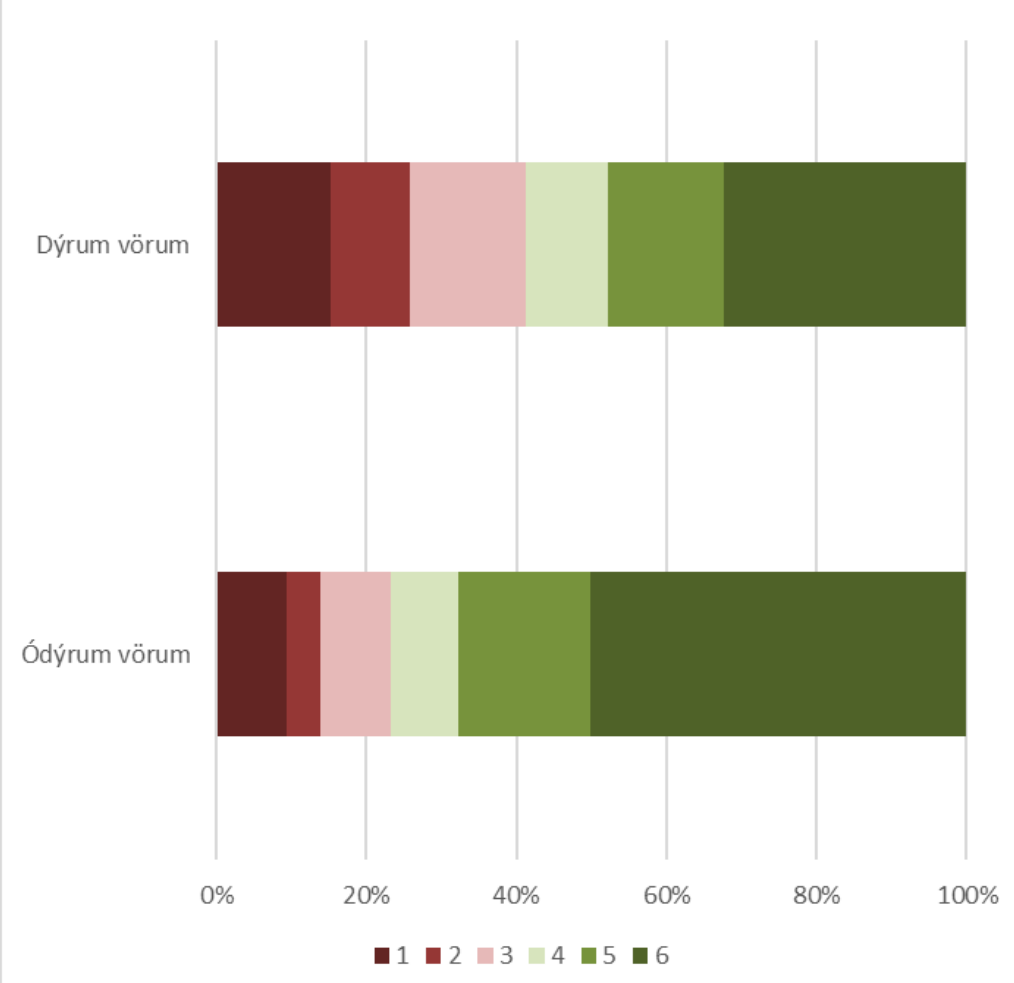

Mynd 7: Viðhorf til vöruflutninga með sjálfakandi ökutækjum annars vegar m.t.t. eftirlits og hins vegar m.t.t. verðmætis vöru. 


\section{Heildarakstur}

Mynd 8 sýnir viðhorf svarenda til áhrifa sjálfakandi tækni sem myndi leiða til breytinga á stað̌setningu á vinnustað, búsetustað̃ og lengdar ferðatíma á dag.

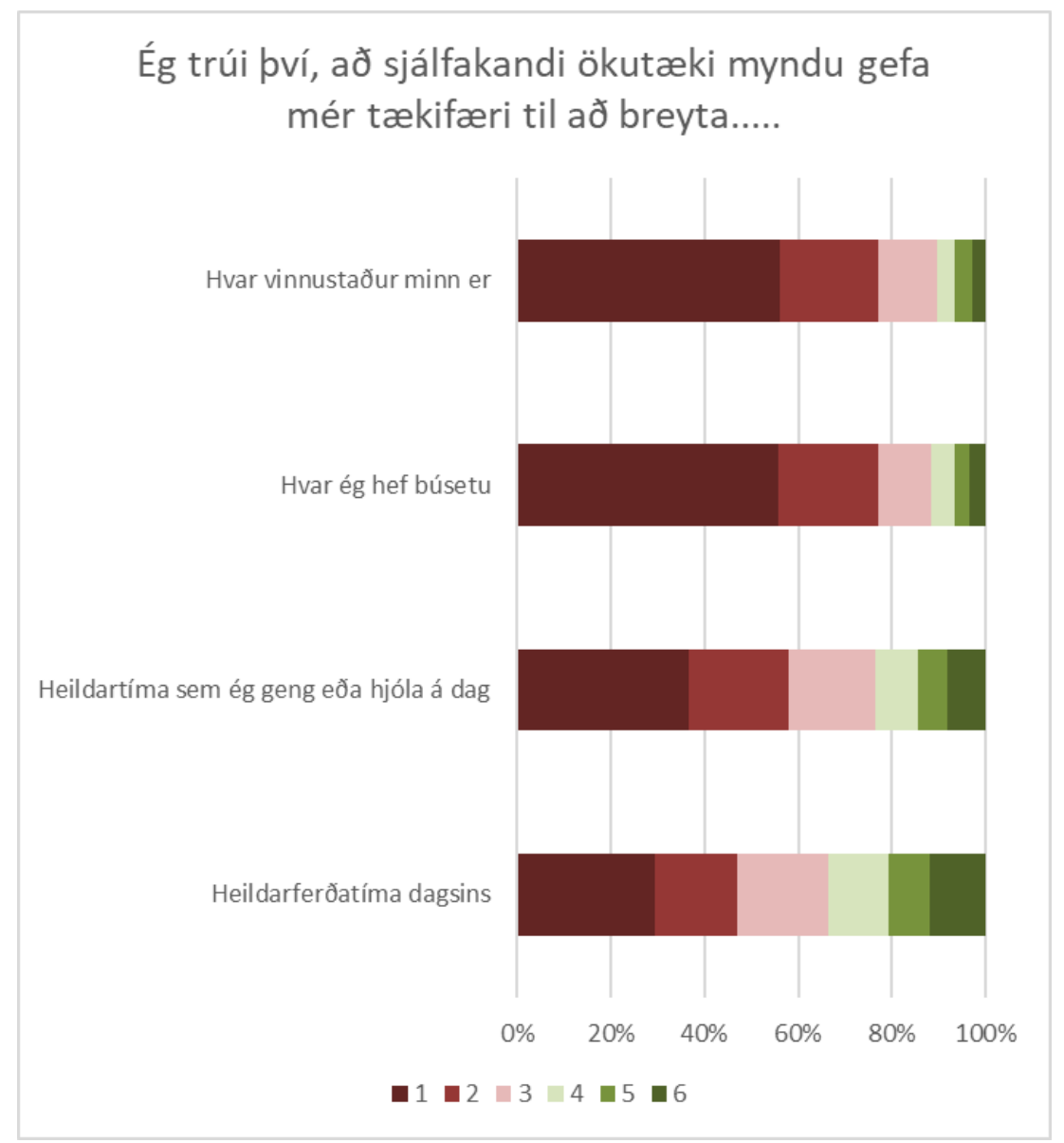

Mynd 8: Breytingar á staðsetningu og ferðatíma.

Svarendur hafa litla trú á pví aơ staơsetning vinnustaðar og búsetu muni breytast. Upprunalega var talið að par sem hægt væri að̃ vinna á meðan á ferðum stæði myndu notendur vera tilbúnir til að̃ ferðast lengur í og úr vinnu ef í boði væri ódýrara húsnæði fjær vinnustað (Meyer et al., 2017). Á sama tíma myndi petta leiða til afleiddrar umferðar (e. Induced demand) og aukins heildaraksturs í kerfinu. Hins vegar, m.v. niðurstöður í undirkaflanum „Nýting ferðatíma sem farpegi i sjálfakandi ökutæki“ par sem svarendur gáfu pað upp að vera síđur tilbúnir til að „vinna“ á meðan á ferð stæði, pá myndi slík breyting á búsetu falla um sjálfa sig. 


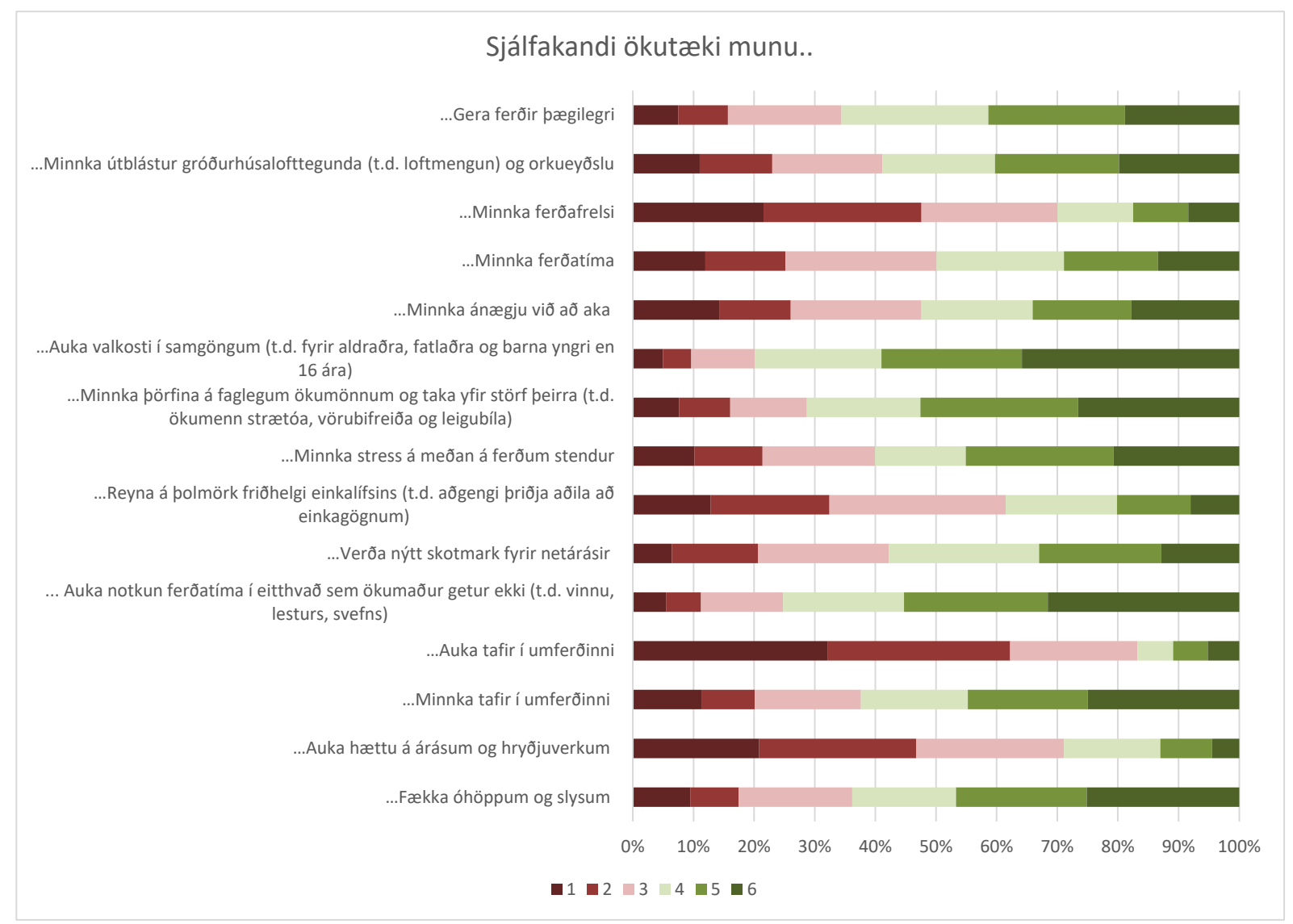

Mynd 9: Ýmis áhrif sjálfakandi ökutækja.

\section{Áhrif á umferðartafir}

Mynd 9Error! Reference source not found. sýnir samantekt á svörum svarenda varðandi áhrif sjálfakandi ökutækja. Svarendur telja að ferðir verði almennt pægilegri, að minnka megi útblástur og að̃ auka megi ferðafrelsi. Á sama tíma og svarendur skiptast nokkurn veginn jafnt í peirri trú að heildarferðatími aukist eða minnki, pá trúa flestir svarenda að umferðartafir minnki.

Einungis $75 \%$ virðast trúa pví að við að ökumaður gerist farpegi, pá skapist meira svigrúm til að farpegi geti sinnt frekari verkefnum sem ökumaður getur annars ekki sinnt. Merkilegt er pó að einungis $65 \%$ svarenda telja að óhöppum og slysum fækki prátt fyrir að $90 \%$ slysa gerist af mannavöldum (Fagnant \& Kockelman, 2015). Svarendur virðast enn tortryggnir gagnvart tækninni, sem er vel réttlætanlegt enda hafa bílslys sjálfakandi ökutækja fengiơ mikla umfjöllun í fréttum síðan tæknin fékk tilraunaréttindi og/eða veriơ notuð í bílum búnum sjálfakandi eiginleikum (AAA, 2019).

\section{Bílastæðaleit}

Einn af peim páttum sem talið er að̃ komi til með að stytta ferðatíma er tími sem færi annars í að leita að bílastæði. Pað má hugsa sér að peim farpegum sem koma í eigin bíl verði hleypt út í nálægð við áfangastað og bíllinn síðan halda áfram og leggja sér sjálfur. Ef ferðin er í samfloti myndi bíllinn ekki purfa að leggja heldur getur bifreiðin haldið á næsta áfangastað.

Pessi eiginleiki er bæði farpeganum í hag m.t.t tímasparnaðar og eigendum bílastæðainnviða par sem nýta mætti lóðir betur. Pörf verður á bílastæðainnviðum par sem geyma má bíla 
pegar peir eru ekki í notkun. Ef bílar eru í einkaeigu purfa peir að vera nálægt heimili eiganda en ekki endilega beint fyrir utan heimili peirra (Elvarsson et al., 2020).

\section{Gagnaöryggi}

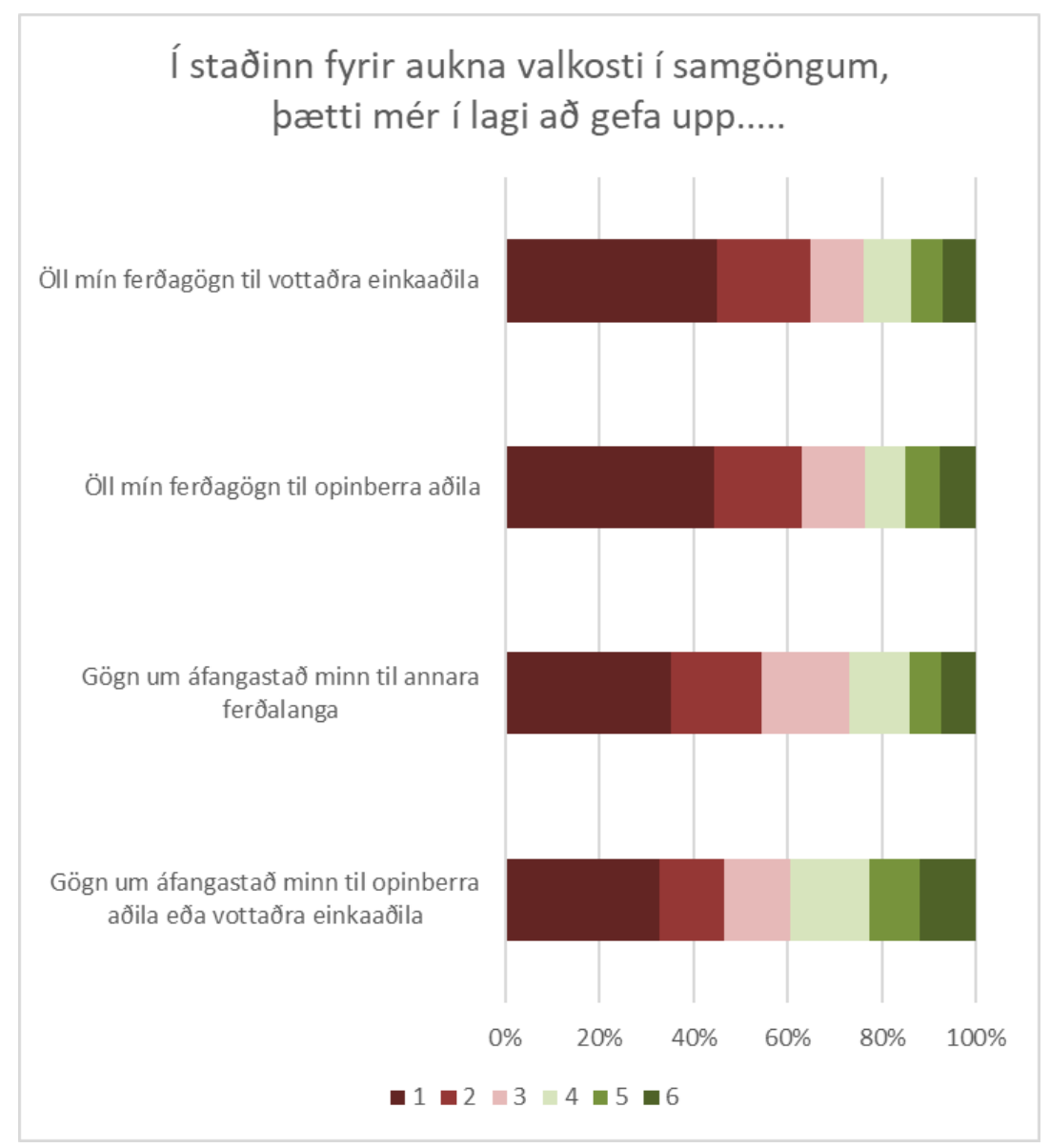

\section{Mynd 10: Viðskipti ferðagagna}

Óneitanlega er áhugi gagnadrifinna fyrirtækja á ferðavenjum mikill. Móðurfyrirtæki Google hefur verið afar drífandi í frampróun sjálfakandi tækni í gegnum dótturfyrirtækið Waymo. Mynd 10 sýnir að̃ fólk er afar varkárt í að gefa eftir gögn sín í skiptum fyrir aukna valkosti í samgöngum. Hins vegar hefur reynslan sýnt að̃ notagildi pjónustu geti fengið notendur til að̃ hunsa áhyggjur af gagnaöflun fyrirtækja sem pau stunda viőskipti við̄, eins og Facebook. Pessi neikvæða afstaða gæti pó einnig verið sökum bjögunar úrtaksins, par sem úrtakið er heldur tekjuhærra en íbúar almennt. Kyriakidis og félagar greindu frá peirri niðurstöðu að tekjuhærri eru gagnrýnni m.t.t. pess að láta gögn af hendi (2015).

\section{Prófanir}

Mynd 11 sýnir að hátt í 70\% svarenda væru sáttir við að sjálfakandi ökutæki væru prófuð í hverfi peirra og rétt rúmlega $60 \%$ svarenda er jákvæour gagnvart pví að taka sjálfir pátt í slíkum prófunum. Prátt fyrir að fólk sé tvístíga um ágæti tækninnar er fólk viljugt til að prófa og athuga hvort hún henti. Pessar niðurstöður benda til enn meiri jákvæðni en sýnt var í íslenskri rannsókn fyrir tveimur árum (Ingimarsson og Jóhannesson, 2018). 


\section{Vinsamlegast gefðu upp hversu sammála pú ert sérhverjum eftirfarandi fullyrðinga:}

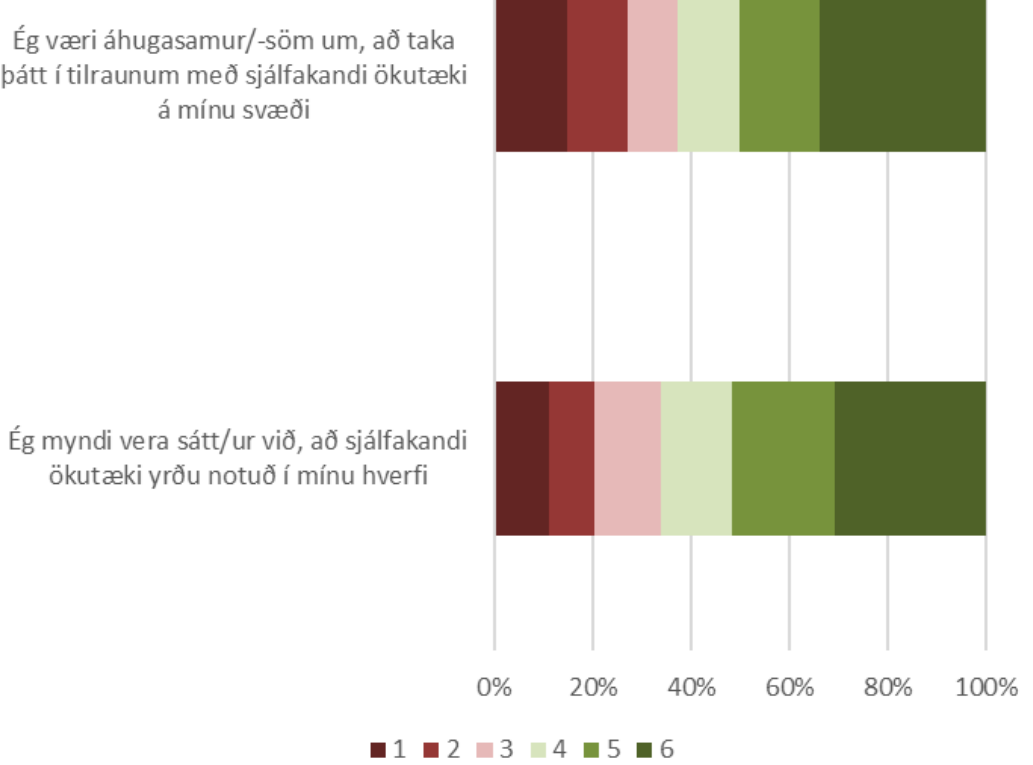

Mynd 11: Viðhorf svarenda gagnvart prófunum sjálfakandi ökutækja í grennd við sig

Við mat á pví hvort ferðamáti henti farpegum parf að taka tillit til ferðatíma, ferðakostnaðar, tíoni ferða, áreiðanleika ferðamáta og fleiri pátta. Fyrir sjálfakandi almenningsvagn í Stokkhólmi kynntu Guo, Susilo, Antoniou \& Brenden (2020) upplifun notenda af pjónustunni. Pau telja upp (1) ferðahraða og ferðatíma, (2) áreiðanleika og hentugleika og (3) öryggistilfinningu sem helstu pætti til að̃ útskýra notkun pjónustunnar.

\section{Umræða}

\subsection{Framtíð samgangna}

Margir rannsakendur hafa sýnt fram á mikinn kerfislegan ávinning sem ná má pökk sé sjálfakandi tækni ef farpegar nýta bíla í deilipjónustu í stað̃ bíla í einkaeigu (Bösch et al, 2016; OECD, 2015). Draga má úr umferð ef farpegar sjá aukið notagildi í pví að ferðast í samfloti í stað pess að ferðast einir. ${ }^{1}$ Alls ekki er víst að sú verði raunin. Til pess að vinna að slíkum ávinningi gætu stjórnvöld sett sér pau markmið að draga úr bílaeign (sér í lagi fjölda bíla á heimili) og auka markaðshlutdeild ferða í samfloti og/eða almenningssamgangna.

Ef svo er, pá má nýta Mynd 6 fyrir stjórnvöld til aơ vita hvenær pau vilja grípa inn í. Ef rýna á betur í bílaeign íbúa parf pó að̃ hafa í huga öryggissjónarmið sem fram koma t.d. í niðurstöðukafla „Öryggi á međan á ferð stendur“ og lýðfræðileg sjónarmið hvers heimilishalds. Ýmis heimili reiða sig t.d. á bílinn til að flytja yngri börn milli staðaa og í ferðir til

\footnotetext{
${ }^{1}$ Höfundar leggja engan dóm á sýn einstaklinga til að eiga farartæki, eða hversu mörg farartæki, en óneitanlega er flutningsgeta samgöngukerfis í persónum talin meiri ef fleiri einstaklingar deila einum bíl í samanburði við að hver einstaklingur ferðist einn í bíl, að̃ öðru óbreyttu.
} 
innkaupa. Ekki verður fullyrt að öll heimili komist af án eigin ökutækis, pó vissulega næðist kerfislegur ávinningur ef færri bílar væru í kerfinu en nú.

Farveitur munu að öllum líkindum fyrst um sinn sjá hag sinn í pví að takmarka flota sinn við ferðir innan og í kring um höfuðoborgarsvæððio. Pað̃ má pó ímynda sér að̋ byggðakjarnar á landsbyggð̃inni séu pjónustað̋ir af færri bílum sem kynni að purfa að̃ panta með lengri fyrirvara.

Hlutfallslega munu strætisvagnar ná að hagræða mest í rekstri m.v. alla aðra ferðamáta (Bösch et al., 2018). Rekstur strætisvagna og sambærilegra ferðamáta gæti pví tekið stakkaskiptum með aukinni sjálfvirkni. Tilraunaverkefni eru pegar í bígero á íslenskri grundu. (Efla, 2020). Vanda verður vissulega til verka, nýta tækifærið til að kynna ferðamátana fyrir íslenskum almenningi og fylgja verkefninu vel eftir. Pegar litið er til framtíðar skal hugsað til peirra pátta sem helst hafa áhrif á hvernig notendur upplifðu pjónustuna sbr. (Guo et al., 2020).

\subsection{Mælistikar til mats á nýjum ferðamátum}

Til að meta betur áhrif nýrra ferðamáta á samgöngukerfi sem heild leggja höfundar til nokkra mælistika til pess að̃ athuga áhrif nýrra ferðamáta á kerfið auk heildarferðatíma, -kostnaðar og -tafa.

\section{Aðgengileiki}

Fyrst og fremst hlýtur pað að teljast til styrkleika samgöngukerfis ef pað reynist aðgengilegt og sé sem fæstum takmörkunum háð. Til að mæla ferðafrelsi fólks má pví einnig mæla aðgengileika kerfisins. Hansen (1959) var meðal peirra fyrstu til að̃ leggja til notkun aðgengileika (e. Accessibility) sem Meyer et al. notuðu til að̃ greina áhrif sjálfvirkra ökutækja á samgöngukerfi (2017). Aðgengileika að einhverjum stað i innan kerfis $A_{i}$ má skilgreina sem summu allra tækifæra og athafna staðsettum á stað j sem stunda má í nálægð̃ við staðinn i, $X_{j}$ og má vigta með falli af alhæfðum kostnaði pess að komast á milli i og j:

$$
A_{i}=\sum_{c_{i j}} X_{j} \cdot f\left(c_{i j}\right)
$$

Ljóst er að par sem biðtími í almenningssamgöngum telst til heildarferðatíma, myndi að̃gengileiki t.d. aukast við aukna tíoni leiða. Einn helstu kosta mælistikans er hversu almenn skilgreiningin er og að stikinn mælir hve gott aðgengið er bæði til og frá stað i.

\section{Bílaeign}

Eins og bent hefur verið á er bílaeign vissulega mælistiki til að fylgjast með. Bösch et al. (2018) hafa bent á að kostnaður hverrar ferðar með sjálfakandi bíl í einkaeigu er talsvert lægri en með öðrum sjálfakandi ökumátum ef maður á pegar bíl. Heildarkostnaður ferðarinnar mun pó enn haldast hærri en sambærileg ferơ með bíl í deilipjónustu eða almenningsvagni. Mikilvægt er að fylgjast með próun bílaeignar á hverja 1000 íbúa sem og hversu marga bíla hvert heimili á.

\section{Fjöldi bílastæða}

Er bílaeign eykst, liggur pað í augum uppi að eftirspurn eftir bílastæðum muni einnig aukast. Slíkt mun hafa áhrif á landnýtingu og fasteignaverð. Ef bílastæði er ekki til staðar neyðist sjálfakandi bíl í einkaeigu til að̃ aka í hringi í kringum áfangastaðinn eða aka tómur í næsta erindi eða til baka til heimilis eigandans, par sem bílastæði er að finna. Slíkt mun auka umferð. 


\section{Ferðatími, hlutfall tafa af ferðatíma}

Auk pess að fylgjast með heildarferðatíma ferðalanga í kerfinu er einnig mikilvægt að fylgjast með hlutfalli tafa af ferðatíma. Pó niðurstöður fræðimanna bendi til minni líkinda á pví að hægt sé að nýta ferðatímann til vinnu má pó vera að sú verði ekki raunin (Kyriakidis et al, 2015; Schoettle \& Sivak, 2014; Correia et al., 2019). Pví gæti pol gegn lengri ferðatíma aukist með tilheyrandi áhrifum á tafatíma í kerfinu aðo öðru óbreyttu.

\section{Hlutfall vöruflutninga}

Talið er að eftirspurn eftir vöruflutningum muni snaraukast. Pað er pví verðugt verkefni að fylgjast með pví hvort ökutæki fari ferðir til vöruflutninga eða til persónuflutninga og slíkt sé einnig skoðað eftir tíma dags. Petta gæti gefið góða innsýn inn í pað hvernig mætti stýra umferðarflæðinu á sem bestan máta háo eftirspurn á hverjum tíma fyrir sig.

\section{Fjöldi einstaklinga á ökutæki og fero}

Flæðigeta samgöngukerfis er gjarnan reiknuð sem fjöldi ökutækja á klukkustund. Samfélagslegur ávinningur felst pó í pví að hámarka fjölda fólks og vara á klukkustund, en ekki fjölda ökutækja. Pá mætti vigta styttri ferðir sem betri en lengri ferðir. Fylgast ætti pví með hlutfalli ferða sem farnar eru í samfloti og meðaltali einstaklinga á ökutæki (e. Occupancy rate), sérstaklega ef gjaldtaka veggjalda yrơi slíkum mælistikum háo.

\subsection{Framkvæmd rannsóknarinnar}

561 einstaklingur búsettur á Íslandi tók pátt í rannsókninni og fyllti út spurninglistann. Sjá má af samanburði lýðfræðilega stærða úrtaksins og íbúa á Íslandi að svörun er góð en hallar á kvenkyns, unga (16-19 ára), aldraða (80+), lítio menntaðra, bíllausa og ökuskírteinislausa. Svarendur bjuggu almennt á heimilum með hærri meðaltekjur, staðsettum á höfuð̋borgarsvæðinu.

Rannsókninni var dreift meðal almennings, en ekki á markvissan hátt eftir slembiúrtaki eða dæmigerðu úrtaki. Var petta gert vegna pess að̃ ekkert fjármagn var ætlað í dreifingu rannsóknarinnar. Næst pegar pessi eða sambærileg rannsókn er framkvæmd skal huga að pví aơ fá eins dæmigert úrtak og völ er á.

Par sem úrtakið er ekki dæmigert, leiðir slíkt til pess að svör geta verið bjöguð, eins og t.d. að hærri tekjur úrtaks kunni að̃ leið̃a til bjagaðra niðurstað̃a m.t.t. trausts á við̋skiptum gagna (sjá niðurstöðukafla „Gagnaöryggi“.

Einnig gefa niðurstöður pær sem greint er frá í pessari grein ekki kost á pví að framkvæma tölfræðigreiningu eða skoða marktækni svaranna. Slíkt er vissulega hægt með greiningu á strjálum vallíkönum sem byggð eru á marktækni hvers stika líkt og framkvæmt var af Etzioni og félögum (2020). Slíkar rannsóknir auk tölfræð̌ilegrar greiningar á fylgni milli einstakra pátta og viðhorfa mætti framkvæma í frekari rannsóknum,

\subsection{Frekari rannsóknir}

Auk rannsókna á mælistikunum hér að̃ ofan má áætla að̃ greining niðurstað̃na strjála vallíkansins væri afar áhugavero líkt og Etzioni et al. hafa sýnt (2020). Greina mætti niðurstöðurnar betur til að̃ skilja frekar hvað̃a lýðfræðilegu pættir hafa helst til áhrif á ferðahegðun.

Petta mætti skoða með pví að bæta við ferðadagbókum í gagnasöfnun tengdu manntali Hagstofunnar hverju sinni líkt og hefur verið gert í Sviss (Weis et al., 2020). 
Einnig mætti bera niðurstöðurnar saman við grunnlíkan samgangna á höfuðborgarsvæðinu, sem og samgöngulíkan meő öorum breytingum t.a.m. Borgarlínu.

Ef framkvæma ætti rannsóknina aftur mætti innifela fleiri ferðamáta til að fá heildarsýn á allt úrval ferðamáta sem ferðalangur hefur hverju sinni.

Skoða mætti betur pau gögn sem ökutækið og farveitur safna hverju sinni og hvaða gögn mætti nýta til pess að stýra umferðarflðði betur og m.t.t. til parfa veghaldara eins og t.d. viōhaldi. Gagnaöflun líkt og önnur frekari atriði purfa auðvitað að̃ standast kröfur setts lagaramma og parf að̃ skoða slíkt vandlega.

Petta mætti skoða í tilraunaskyni samhliða fyrstu prófunum ferðamátanna hérlendis. Við prófanir er einnig mikilvægt að̋ sannreyna við̌horf farpega fyrir og eftir ferðina. Enn er óstaðfest að draga muni úr umferðaróhöppum eins og hefur verið rakið í pessari grein. NHTSA greinir frá pví að 94\% slysa eru af mannavöldum en innviðaeigendurnir líta ekki svo á að rekja megi slys til hönnunar innviðanna. Lagt er til að umferðaröryggi sé skoðað nánar með tilliti til aukinnar sjálfstýringar og hvernig megi best meta áhrif sjálfakandi ökutækja á umferðaröryggi í formi mælistika.

Síðast en ekki síst er vert að minnast á pað að uppi hafa verið áform um setningu veggjalda á íslenskum vegum. Kílómetraháð veggjöld gætu reynst markvisst tól til að lágmarka ekna heildarkílómetra og fækka tómum ferðum pegar bílar verða fyllilega sjálfakandi og minnka pannig tafir. Hafa parf í huga hvernig mismunandi form veggjalda kunna að̃ hafa áhrif á umferð og viðhorf almennings til nýs raunveruleika sjálfakandi ferðamáta.

\subsection{Lokaorð}

Pessi grein fjallar um ýmis viðhorf almennings gagnvart sjálfakandi ökutækjum og pau borin saman við evrópskar niðurstöður Eurobarometer. Á sama tíma og farpegum sjálfakandi ökutækis líður betur en óvörðum farpegum í nálægð ökutækisins er víst að stórum hluta fólks lið̌i betur sem farpega með eftirlit öryggisfulltrúa í ökutækinu. Pá er alls óvíst aơ fólk sé tilbúið að senda börn sín með ökutækinu. Svarendur voru almennt jákvæðari gagnvart pví að flytja vörur á milli staða með sjálfakandi tækni. Prátt fyrir petta er $70 \%$ svarenda jákvæðir gagnvart pví að tæknin sé prófuơ í eigin nágrenni og 60\% jákvæðir gagnvart pví að prófa tæknina sjálfir.

Niðurstöður rannsóknarinnar eru nýmæli á Íslandi og bundnar eru vonir við frekari rannsóknir á ferðamátavali m.t.t. hugsanlegra ferðamáta er fram líoa stundir.

Höfundaframlag: Hugmyndafræði, A.E.; aðferðafræði, A.E. and H.S; formleg greining, A.E.; rannsókn, A.E og H.S.; gagnaúrvinnsla, A.E.; skrif—upprunaleg drög, A.E.; skrif—rýni og yfirferð, A.E og H.S; umsjón, A.E.; verkefnastýring, A.E. Allir höfundar hafa lesið̌ og sampykkt innsent handrit. Höfundar hafa allir lagt til töluvert framlag til rannsóknar pessarar.

Frekari pakkir: Við rannsóknir hafa höfundar notiơ góðs af samstarfi innan COST-hópsins "Wider Impacts and Scenario Evaluation of Autonomous and Connected Transport" (WISEACT, COST-Action CA16222). Pá er Vegagerðinni, Verkfræðingafélagi Íslands, Bílgreinasambandinu, Skipulagsstofnun, Háskóla Íslands, og Landbúnaðarháskólanum á Hvanneyri pakkað kærlega fyrir viðleitni sína í að dreifa spurningalistanum meðal meðlima, starfsfólks, nemenda og víðar. Tveimur nafnlausum ritrýnendum er kærlega pakkað fyrir sitt framlög til að bæta greinina fyrir birtingu. 


\section{Heimildaskrá}

1. AAA (2019) Automated vehicle survey - Phase IV, Factsheet, American Automobile Association.

2. Ainsalu, J., Arffman, V., Bellone, M., Ellner, M., Haapamäki, T., Haavisto, N., Josefson, E., Ismailogullari, A., Lee, B., Madland, O., Madzulis, R., Müür, J., Mäkinen, S., Nousiainen, V., Pilli-Sihvola, E., Rutanen, E., Sahala, S., Schønfeldt, B., Smolnicki, P. M., Soe, R.-M., Sääski, J., Szymanska, M., Vaskinn, I \& Åman, M. (2018) State of the art of automated buses, Sustainability, 10(9), 3118. https://doi.org/10.3390/su10093118

3. Ambühl, L., Ciari, F. \& Menendez, M. (2016) What about space? A simulation based assessment of AVs impact on road space in urban areas, Proceedings of $16^{\text {th }}$ Swiss transport research conference, Ascona.

4. Anania, E. C., Rice, S., Walters, N.W., Pierce, M., Winter, S.R. \& Milner, M.N. (2018) The effects of positive and negative information on consumers' willingness to ride in driverless vehicle, Transport Policy, 72, 218-224.

5. Atasoy, B., Glerum, A. \& Bierlaire, M. (2012) Attitudes towards mode choice in Switzerland, Report, Transp-Or 110502, EPFLausanne

6. Becker, H. (2016) Verkehrsplanung für das zeitalter des autonomen fahrens, presentation, VöV, Lugano, Switzerland.

7. Becker, F., Bösch, P., Ciari, F. \& Axhausen, K. W. (2016) Entwicklung konsistenter Szenarien für die Einführung autonomer Fahrzeuge, Working Paper, Institute of Transport Planning and Systems, ETH Zürich.

8. Ben-Akiva, M. \& Lerman, S. (1985) Discrete Choice Analysis: Theory and Application to Travel demand, MIT Press, Cambridge, MA, ISBN: 9780262022170

9. Bollason, S. (2016) Sjálfakandi bílar: Rýni aðstæơna á Íslandi, Skýrsla, Rannsóknarsjóður Vegagerðarinnar, sótt pann 12.9.2020 af https://www.vegagerdin.is/vefur2.nsf/Files/sjalfakandi bilar/\$file/Sj\%C3\%A1lfakandi\%20b $\%$ C3\%ADlar.pdf

10. Byggðastofnun (2018) Atvinnutekjur 2008-2017 eftir atvinnugreinum og landshlutum, skýrsla og töluleg gögn, Byggðastofnun.

11. Bösch, P.M., F. Ciari \& K.W. Axhausen (2016) Autonomous vehicle fleet sizes required to serve different levels of demand, Transportation Research Record, 2542, 111 119.

12. Bösch, P.M., Becker, F., Becker, H. \& Axhausen, K.W. (2018) Cost-based analysis of autonomous mobility services, Transport Policy, 64, 76-91.

13. Childress, S., Nichols, B., Charlton, B. \& Coe, S. (2015) Using an activity-based model to explre the potential impacts of automated vehicles, Transportation Research Record, 2493, 1, 99-106. https://doi.org/10.3141/2493-11

14. Correia, G. H. d. A, Looff, E., van Cranenburgh, S., Snelder, M. \& van Arem, B. (2019) On the impact of vehicle automation on the value of travel time while performing work and leisure activities in a car: Theoretical insigths and results from a stated 
preference survey, Transportation Research Part A: Policy and Practice, 119, 359-382. https://doi.org/10.1016/i.tra.2018.11.016

15. Deloitte (2019) Global automative consumer study: Advanced vehicle technologies and multimodal transportation, Skýrsla, Global focus countries.

16. Efla (2020) Er Ísland tilbúiơ til aơ taka á móti sjálfakandi almenningsvagni? Rannsóknarverkefni, Skýrsla, óútgefin.

17. Elvarsson, A. B., Martani, C., \& Adey, B. T. (2020) Considering automated vehicle deployment uncertainty in the design of optimal parking garages using real options, Journal of Building Engineering, in Press, online since 13.8.2020 at https://doi.org/10.1016/j.jobe.2020.101703

18. Eurobarometer (2020) Special Eurobarometer 496: Expectations and Concerns from a Connected and Automated Mobility, Gögn, Directorate-General for Communication, European Commission, S2231_92_1_496_ENG.

19. Etzioni, S., Hamadneh, J., Elvarsson, A. B., Esztergár-Kiss, D., Djukanovic, M., Neophytou, S. N., Sodnik, J., Polydoroupoulou, A., Tsouras, I., Pronello, C., Thomopoulos, N. \& Shiftan Y. (2020) Modeling cross-national differences in automated vehicle acceptance, Sustainability, 12(22), 9765. https://doi.org/10.3390/su12229765

20. Fagnant, D. J. \& Kockelman, K. M. (2015) Preparing a nation for autonomous vehicles: opportunities, barriers and policy recommendations, Transportation Research Part A, 77, 167-181.

21. Fagnant, D. J. \& Kockelman, K. M. (2014) The travel and environmental implications of shared autonomous vehicles, using agent-based model scenarios, Transportation Research Part C, 40, 1-13. https://doi.org/10.1016/j.trc.2013.12.001

22. Guo, J., Susilo, Y., Antoniou, C. \& Brenden, A. P. (2020) Influence of individiual perceptions on the decision to adopt automated bus services, Sustainability, 12 (16) 6484. https://doi.org/10.3390/su12166484

23. Hagstofa (2020) Gögn um lýðfræði úr Lífskjara- og Vinnumarkaðsrannsóknum, Hagstofa Íslands.

24. Hansen, W. (1959) How accessibility shapes land use, Journal of the American Institute of Planners, 25 (2) 73-76.

25. Harper, C.D., Hendrickson, C., Mangones, S. \& Samaras, C. (2016) Estimating potential increasesi $n$ travel with autonomous vehicles for the non-driving, elderly and people with travel-restrictive medical conditions, Transportation Research Part C: Emerging technologies, 72, 1-9. https://doi.org/10.1016/j.trc.2016.09.003

26. Hartmann, M., Motamedidehkordi, N., Krause, S., Hoffmann, S., Vortisch, P. \& Busch, F. (2017) Impact of Autonomous Vehicles on Capacity of the German Freeway Network, paper accepted for presentation at ITS World Congress, Montreal, October 2017.

27. Iclodean, C., Cordos, N. \& Varga, B. O. (2020) Autonomous shuttle bus for public transportation: A review, Energies, 13 (11), 2917. https://doi.org/10.3390/en13112917

28. Ingimarsson, S. K. \& Jóhannesson, T. H. (2018) Eiga sjálfstýrðir bílar framtíð á Íslandi?, BS ritgerð, Háskólinn í Reykjavík. 
29. Jara-Díaz, S. R. (1998) Time and income in travel demand: towards a microeconomic activity framework, University of Chile.

https://www.researchgate.net/publication/228886939 Time and income in travel dema nd towards a microeconomic activity framework

30. Kyriakidis, M., Happee, R. \& de Winter, J. (2015) Public opinion on automated driving: Results of an international questionnaire among 5000 respondents, Transportation Research Part F: Traffic Psychology and Behaviour, 32, 127-140. https://doi.org/10.1016/i.trf.2015.04.014

31. Kyriakidis, M., Sodnik, J., Stojmenova, K., Elvarsson, A.B., Pronello, C. \& Thomopoulos, N. (2020) The Role of Human Operators in Safety Perception of AV Deployment-Insights from a Large European Survey - The safety illusion, Sustainability, 12(21), 9166; doi: 10.3390/su12219166

32. Le Vine, S., Zolfaghari, A. \& Polak, J. W. (2015) Autonomous cars: The tension between occupant experience and intersection capacity, Transportation Research Part C, $52,1-14$.

33. Mannvit (2019) Áhrif sjálfvirkni í bílum á umferðarrýmd, Skýrsla, Rannsóknarsjóður Vegagerðarinnar, sótt pann 12.9.2020 af

https://www.vegagerdin.is/vefur2.nsf/Files/ahrif_sjalfvirkni_bila_umferdarrymd_skyrsla/\$fil e/\%C3\%81 hrif\%20sj\%C3\%A1lfvirkni\%20\%C3\%AD\%20b\%C3\%ADlum\%20\%C3\%A1\%20 umfer\%C3\%B0arr\%C3\%BDmd.pdf

34. Mannvit (2020) Áhrif 5G á samgöngur, Skýrsla, Rannsóknarsjóður Vegagerðarinnar, sótt pann 12.9.2020 af http://www.vegagerdin.is/media/rannsoknir/1800-705-Ahrif-5G-asamgonguinnvidi.pdf

35. Manser, P., Becker, H., Hörl, S. \& Axhausen, K.W. (2020) Designing a large-scale public transport network using agent-based microsimulation, Transportation Research Part A: Policy \& Practice, 137, 1-15

36. Meyer, J., Becker, H., Bösch, P.M. \& Axhausen, K.W. (2017) Autonomous vehicles: The next jump in accessibilities?, Research in Transportation Economics, 62, 80-91. https://doi.org/10.1016/..retrec.2017.03.005

37. Narayanan, S., Chaniotakis, E. \& Antoniou, C. (2020). Factors affecting traffic flow efficiency implications of connected and autonomous vehicles: A review and policy recommendation, Advances in Transport Policy and Planning, 5, 1-50.

38. NHTSA (2015) Critical reasons for crashes investigated in the National motor vehicle crash causation survey, Summary, National Highway Traffic Safety Administration, US Department of Transportation, Washington D.C.

39. OECD (2015) Urban mobility system upgrade: How shared self-driving cars could change city traffic, International Transport Forum, OECD.

40. Ríkislögreglustjóri (2020) Gild B-ökuréttindi, gögn, Ríkislögreglustjóri.

41. Rogers, E. (1962) Diffusion of Innovations, Free Press, ISBN 978-0743222099.

42. SAE International. (2014). SAE International's Levels of Driving Automation for onroad vehicles. Retrieved from http://www.sae.org/misc/pdfs/automated driving.pdf. 
43. Sarriera, J.M., Álvarez, G.E., Blynn, K., Alesbury, A., Scully, T. \& Zhao, J. (2017) To share or not to share: Investigating the social aspects of dynamic ride sharing,

Transportation Research Record, 2605, 109-117. DOI: 10.3141/2605-11

44. Schoettle, B. \& Sivak, M. (2014) Public Opinion about Self-Driving vehicles in China, India, Japan, the U.S., the U.K., and Australia, Report, The University of Michigan Transportation Research Institute, Ann Arbor, Michigan, USA.

45. Thomopoulos, N., Pronello, C., Etzioni, S., Raposo, M. A., Grosso, M., Polydoropoulou, A. \& Shiftan, Y. (2020) Survey design and co-ordination for large international AV surveys, Sustainability, í rýni.

46. Yang, L., Choudhury, C. F., Ben-Akiva, M., Abreu e Silva, J., \& Carvalho, D. (2009). Stated Preference Survey for New Smart Transport Modes and Services: Design, Pilot Study and New Revision, MIT-Portugal Program Working Paper Series.

47. Weis, C., Kowald, M., Danalet, A., Schmid, B., Vrtic, M., Axhausen, K.W. \& Mathys, N. (2020) Surveying and analysing mode and route choices in Switzerland 2010-2015, Proceedings of Swiss Transport Research Conference 2020, Lausanne.

48. Weisbaum, H. (2018) Trust in Facebook has dropped by 66 percent since the Cambridge Analytice Scandal, Viðtal við Larry Ponemon, NBC News, sótt pann 02.11.2020 af https://www.nbcnews.com/business/consumer/trust-facebook-has-dropped51-percent-cambridge-analytica-scandal-n867011 